\title{
WATER RESOURCES RESEARCH GRANT PROGRAM PROJECT DESCRIPTIONS, FISCAL YEAR 1992
}

Compiled by Melvin Lew and Pamela Murray

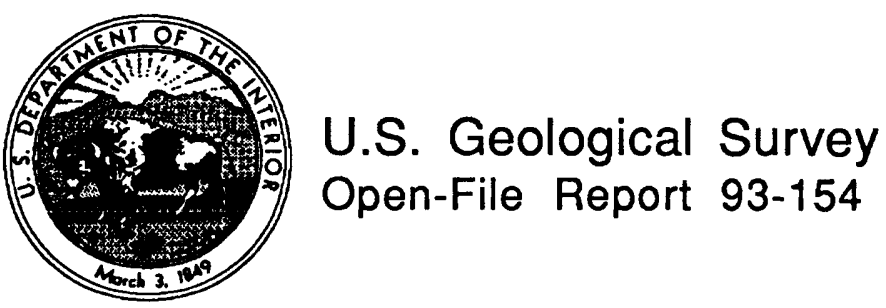

Reston, Virginia

1993 


\title{
U.S DEPARTMENT OF THE INTERIOR \\ BRUCE BABBITT, Secretary
}

\author{
U.S. GEOLOGICAL SURVEY
}

Dallas L. Peck, Director

For additonal information write to:

Chief, Office of External Research

U.S. Geological Survey

Water Resources Division

424 National Center

Reston, Virginia 22092
Copies of this report can be purchased from:

U.S. Geological Survey

Books and Open-File Reports Section

Box 25286, Federal Center

Denver, Colorado 80225 


\section{CONTENTS}

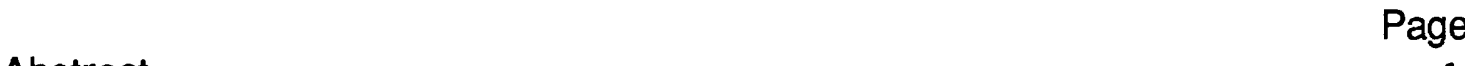

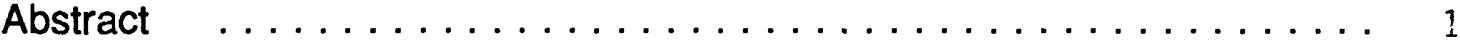

Introduction ............................ 2

Section 1. Project Summaries-Fiscal Year 1992 Grants . . . . . . . . . 6

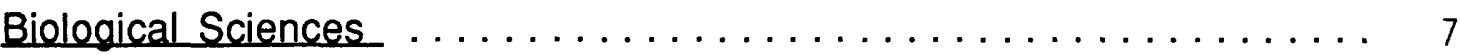

Detection of Hepatitis A and Norwalk Viruses by Polymerase Chain Reaction After Exposure to Water Disinfectants and Its Relationship to Virus Infectivity. (University of California at Irvine) . . . . . . . . 8

Biotic and Abiotic Weathering of Aquifer Rock. (Rensselaer Polytechnic

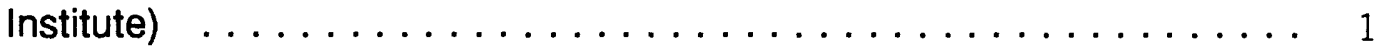

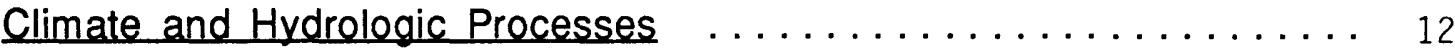

Advection-Aridity Approach for Routine Evaporation Estimation and Subsurface Transport Simulation. (University of California at Davis) . 13

Predictability and Variability of Climate and Hydrology: Inferences from Great Salt Lake Dynamics. (Utah State University) . . . . . . . . 15

Transient Response of Upland Watersheds to Storm Events: A Comparative Study. (University of California at Berkeley) . . . . . . . . 17

The Role of Turbulent Shear Stresses on Pavement Formation and Bedload Motion in Gravel Bed Streams. (Virginia Polytechnic Institute and State University $\ldots \ldots \ldots \ldots \ldots \ldots$

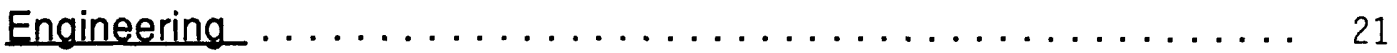

Remediation of Acid Drainage Through Surface Coating of Fe-Sulfides. (University of Kentucky) . . . . . . . . . . . . . . . . . . 22

Innovative Alternative for Sediment Removal from Reservoirs: Phase I. (University of Nebraska). . . . . . . . . . . . . . . . . . . 24

Non-Parametric Stochastic Simulation of Stream Flow in the Colorado River. (Utah State University) . . . . . . . . . . . . . . . 26 
Ground-water Flow and Transport. . . . . . . . . . . . . . 28

Determination of Hydraulic Properties of Unsaturated Soil Using Point Application of Water. (University of Arizona). . . . . . . . . . . . 29

Characterization of the Fate and Transport of Volatile Organic Compounds in Porous Media Under Unsaturated Conditions. (University

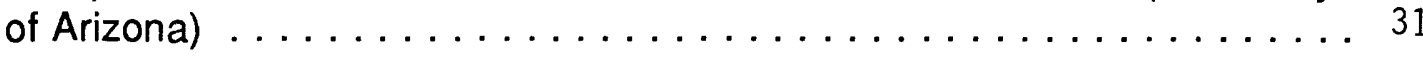

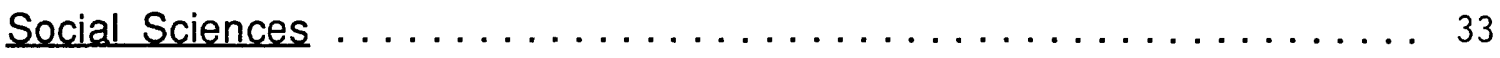

Using Water Banks to Promote More Flexible Water Use. (University

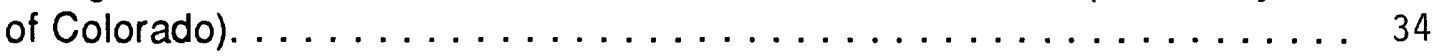

An Analysis of Water Quality Enforcement Strategies and Their Effectiveness in Achieving Water Quality Standards. (West Virginia

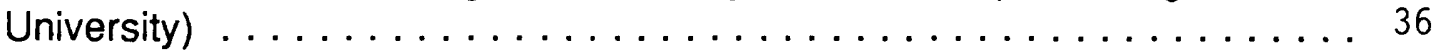

Negotiated Indian Water Rights Settlements: The Efficacy of Negotiation as a Dispute Resolution Strategy. (University of Utah) . . . . . . . 38

Aggregation, Declining Block Prices, and Urban Water Demand in Humid Areas. (University of Illinois) . . . . . . . . . . . . . . . 40

Water Quality .............................. 42

Deep Production in Lakes: Effect on Nutrient Transport, Trace Metal Cycling and Paleolimnology. (Wisconsin Department of Natural

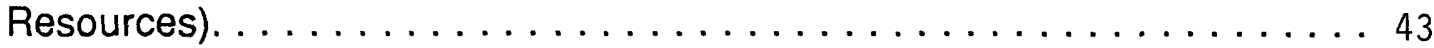

Phosphorus Fourier Transform Nuclear Magnetic Resonance (FT-NMR) Analysis of Organic Phosphorus in the Hydrosphere.

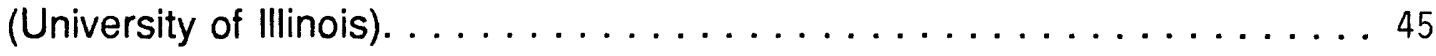

Section II. Summaries of Projects Completed in Fiscal Year 1992 . . . . . . 47

Solute Segregation During Soil Freezing and Solute and Heat Transport in Permafrost. ..................... 48 
Nucleic Acid and Monoclonal Antibody Probes for Bacterial Pollutants of Water Resources Systems . . . . . . . . . . . . . . . . . . 50

Gas Transfer in Streams with Surface Instabilities; White Water Effects and Riffle-Pool Sequences ....................... 51

Drainage Effects on Salinization, Organic Matter, and Selenium in Wetlands Soils ........................... 53

Compatibility of Physically-Based and Linear System Solute Transport Modeling Approaches and Their Conjunctive Application ........ 55

Microbial Dehalogenation of Hexachlorinated PCB at Low Redox Potential . .

A Novel Non-Lethal Field Bioassay for Predicting Stream Water Quality Impaired by Heavy Metals and Low $\mathrm{pH} \ldots \ldots \ldots \ldots \ldots \ldots . \ldots . . \ldots 9$

A Novel Closed Loop Air Stripping Process for Volatile Organic Compounds (VOC) Removal from Contaminated Water. . . . . . . . . . 61

The Effects of Humic Substances on the Interactions of Metal lons with Organisms and Liposomes. ................... 63

A Study of Growth, Resource Allocation, and Nutrient Requirements of Myriophyllum Aquaticum....................... 65

Water Quality Enhancement via Integrative Procedures for Urban Non-point Source Water Pollution and Flood Control. . . . . . . . . . . 67

Ground-water Quality in Pumping Wells Located Near Surface Water Bodies . . . . . . . . . . . . . . . . . . . . . . . . . . . . . . . . .

Microbial Transformations in Alkali Lake, Oregon . . . . . . . . 71

Model for Regional Solute Transport Suited for Calibration and Management.......................... 73 
Institutional Response to a Changing Water Policy Environment. . . . . . 74

Increased Water-Use Efficiency in Alfalfa by Selection for Two Key Heritable Physiological Traits . . . . . . . . . . . . . . . . 75

Economic Impacts of Alternative Water Allocation Instructions in the Colorado River Basin. . . . . . . . . . . . . . . . . . . . . . . . . . . . . . 77

A Field Study for Model Validation of Multi-Dimensional Flow and Transport in the Vadose Zone. . . . . . . . . . . . . . . . . . . . . . . 79

Development of Biologically Relevant Methods for the Determination of Bioavailable Aluminum in Surface Waters . . . . . . . . . . . . 80

Recombinant Organisms in the Drinking Water System: Survival, Plasmid Transfer, and the Role of Surfaces . . . . . . . . . . . 82

Water and Chemical Movement Through the Biologically Active Surface Layer of No-Till Soils. . . . . . . . . . . . . . . . . . . . . . . . . . 84

Variable Density Ground-Water Flow Near a Closed-Basin Saline Lake: A Case of Study at Mono Lake, California. . . . . . . . . . . . . 86

The Effects of Wetting on Transport of Organics in Ground Water . . . 88

Evaluation of Mechanisms of Microbial Alternation and Humification of Polynuclear Aromatic Hydrocarbons (PAHS) for Water Quality

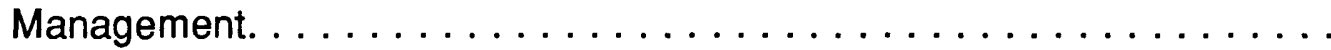

Incorporating Public Preferences in the Optimization of Urban Water Supply Reliability: Planning Procedures and Survey Techniques. ...... 91

Applications of Statistical Methods to Study Climate and Flooding

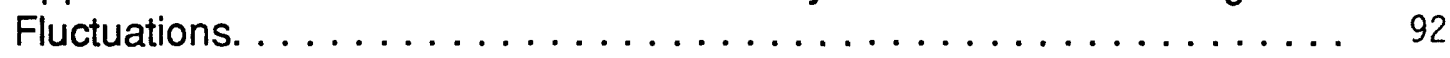

Sources and Accumulation of Trace Metals in Sediments and the Asiatic Clam, Corbicula Fluminea, in Two South Carolina Watersheds . . . . . . . 94

Removal of Contaminants from the Vadose Zone by Pneumatic Fracturing 95 
Study of Model Hydrological Cycle of North America in a Version of the National Center for Atmospheric Research's General Circulation Model. .

State Revolving Loan Funds: Analysis of Institutional Arrangements and Distributive Consequences . . . . . . . . . . . . . . . . . . 99

Special Water Districts: A Tool for Water Quality Management as well as Economic Efficiency . . . . . . . . . . . . . . . . . . . . 100

Impacts of Agricultural Production Practices on the Quantity and Quality of Ground Water in the Central High Plains. . . . . . . . . . . . . 101

An Economic Evaluation of Water Marketing in a Low Transaction Cost Setting. ............................. 103

Development of a Macro-Scale Land Surface Hydrologic Model for General Circulation Models . . . . . . . . . . . . . . . . . . . . . 105

Alternative Institutional Arrangements for Managing in Exhaustible Aquifer: An Analytical Hierarchy Process. . . . . . . . . . . . . . . . 107

Coping with Urban Water Shortages During Drought: The Effects of Legal and Administrative Factors. . . . . . . . . . . . . . . . . 109

Effective Management of Water Resources: A Function of Geomorphology

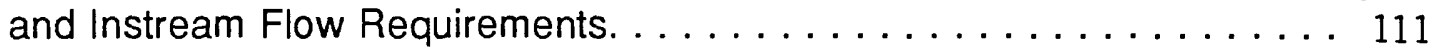

In-Situ Solvent Extraction for Remediation of Coal Tar Sites . . . . . . 112 Effects of Uniconazole on Plant Growth and Water Use . . . . . . . . . . 113 


\section{LIST OF TABLES}

Page

Table:

1. Proposals and Awards by Fiscal Year . . . . . . . . 3

2. Proposals and Awards by Research Interest Area, Fiscal Year $1992 \ldots \ldots \ldots \ldots \ldots \ldots \ldots \ldots$

3. Proposals and Awards by Organization, Fiscal Year $1992 \ldots \ldots \ldots \ldots \ldots \ldots \ldots \ldots \ldots \ldots \ldots \ldots \ldots$ 


\title{
WATER RESOURCES RESEARCH GRANT PROGRAM \\ PROJECT DESCRIPTIONS, FISCAL YEAR 1992
}

Complied by Melvin Lew and Pamela Murray

\begin{abstract}
This report contains information on the 17 new projects funded by the U.S. Geological Survey's Water Resources Research Grant Program in fiscal year 1992 and on 39 projects completed during the year. For the new projects, the report gives the grant number, title, performing organization, principal investigator(s), project duration, and a project description that includes: identification of water-related problems, (2) contribution to problem solution, (3) objectives, and (4) approach. The 17 projects include 2 in the area of biological sciences, 4 in climate and hydrologic processes, 3 in engineering, 2 in ground-water flow and transport, 4 in social sciences and 2 in water quality.

For the 39 completed projects, the report gives the grant number, title, performing organization, principal investigator(s), starting date, date of receipt of final report, and an abstract of the final report. Each project description provides the information needed to obtain a copy of the final report.
\end{abstract}

The report also contains tables showing (1) proposals received according to area of research interest, (2) awards and funding according to area of research interest, (3) proposals received according to type of submitting organization, and (4) awards and funding according to type of organization. 


\section{INTRODUCTION}

In January 1985, the U.S. Geological Survey was assigned responsibility for administering the Water Resources Research Act of 1984 (Public Law 98-242). Section 105 of the act authorize funds for research grants, on a fund-matching basis, to qualified individuals and groups as defined in the law.

From fiscal year (FY) 1985 through FY 1992, 268 of the 2,266 proposals received were awarded grants. The number of research proposals submitted, grants awarded, funds appropriated by Congress and the U.S. Geological Survey Open-File number are presented in Table 1.

In FY 1992, the program funding was significantly lowered, from $\$ 4.358$ million to $\$ 1.765$ million, and the program did not receive an appropriation for $F Y$ 1993. In FY 1992, 262 proposals requesting $\$ 30.5$ million of Federal funding (\$33.2 million of non-Federal funding) were submitted in response to U.S. Geological Survey Announcement No. 7846 issued on August 12, 1991. Of this number, 17 were selected for funding (Table 2). As in previous years, proposals from academic institutions dominated the competition for funds (Table 3).

Section I of the report presents summaries of the 17 proposals selected for funding. Section II presents summaries of the 39 projects completed during FY 1992. 
Table 1--Proposals and Awards by Fiscal Year

Fiscal Proposals Grants Appropriation USGS

Year Submitted Awarded (\$) Millions Open-File

Report

Number

\begin{tabular}{|l|r|r|r|r|}
\hline 1985 & 368 & 24 & 2.543 & $85-687$ \\
\hline 1986 & 299 & 43 & 4.767 & $86-548$ \\
\hline 1987 & 273 & 34 & 4.381 & $88-179$ \\
\hline 1988 & 239 & 38 & 4.381 & $89-249$ \\
\hline 1989 & 260 & 36 & 4.381 & $90-139$ \\
\hline 1990 & 250 & 40 & 4.322 & $91-195$ \\
\hline 1991 & 315 & 36 & 4.358 & $92-161$ \\
\hline 1992 & 262 & 17 & 1.765 & This Report \\
\hline
\end{tabular}


Table 2--Proposals and Awards by Research Interest Area, Fiscal Year 1992

\section{Proposals}

\begin{tabular}{|c|c|c|c|c|}
\hline Interest Area & No. & $\begin{array}{l}\text { Federal } \\
\text { Funds (\$) }\end{array}$ & $\begin{array}{l}\text { Non-Federal } \\
\text { Funds (\$) }\end{array}$ & $\begin{array}{c}\text { Total } \\
\text { Funds (\$) }\end{array}$ \\
\hline $\begin{array}{l}\text { Ground-Water Flow and } \\
\text { Transport }\end{array}$ & 35 & $4,462,718$ & $4,766,204$ & $9,228,922$ \\
\hline Engineering & 56 & $6,352,854$ & $6,677,802$ & $13,030,656$ \\
\hline Water Quality & 44 & $5,058,727$ & $5,426,176$ & $10,484,903$ \\
\hline Biological Science & 32 &, 317 & $4,042,232$ & $7,797,549$ \\
\hline Social Sciences & 42 & $4,747,852$ & $5,915,274$ & $10,663,126$ \\
\hline $\begin{array}{l}\text { Climate and } \\
\text { Hydrologic Processes }\end{array}$ & 53 & $6,153,909$ & $6,409,300$ & $12,563,209$ \\
\hline Totals & 262 & $30,531,377$ & $33,236,988$ & $63,768,365$ \\
\hline
\end{tabular}

Awards

\begin{tabular}{l|r|r|r|r|}
\multicolumn{1}{l}{} & \multicolumn{1}{c}{$\begin{array}{c}\text { Federal } \\
\text { Interest Area }\end{array}$} & \multicolumn{1}{c}{$\begin{array}{c}\text { Non-Federal } \\
\text { Funds (\$) }\end{array}$} & \multicolumn{1}{c}{$\begin{array}{c}\text { Total } \\
\text { Funds }(\$)\end{array}$} & \multicolumn{1}{c|}{ Funds $(\$)$} \\
\hline $\begin{array}{l}\text { Ground-Water Flow and } \\
\text { Transport }\end{array}$ & 2 & 274,258 & 280,102 & 554,360 \\
\hline Engineering & 3 & 259,974 & 261,640 & 521,614 \\
\hline Water Quality & 2 & 244,659 & 288,934 & 533,593 \\
\hline Biological Sciences & 2 & 261,126 & 261,797 & 522,923 \\
\hline Social Sciences & 4 & 270,400 & 272,584 & 542,984 \\
\hline $\begin{array}{l}\text { Climate and } \\
\text { Hydrologic Processes }\end{array}$ & 4 & 452,910 & 611,346 & $1,064,256$ \\
\hline Totals & 17 & $1,763,327$ & $1,976,403$ & $3,739,730$ \\
\hline
\end{tabular}


Table 3.--Proposals and Awards by Organization, Fiscal Year 1992

Proposals

\begin{tabular}{|c|c|c|c|c|}
\hline Organization & No. & Federal $(\$)$ & $\begin{array}{l}\text { Non-Federal } \\
\text { Funds }(\$)\end{array}$ & $\begin{array}{l}\text { Total } \\
\text { Funds }(\$)\end{array}$ \\
\hline $\begin{array}{l}\text { Academic } \\
\text { Institutions }\end{array}$ & 253 & $29,788,588$ & $32,425,429$ & $62,214,017$ \\
\hline $\begin{array}{l}\text { Non-Federal } \\
\text { Government }\end{array}$ & 4 & 458,344 & 524,884 & 983,228 \\
\hline Private & 5 & 284,445 & 286,675 & 571,120 \\
\hline Total & 262 & $30,531,377$ & $33,236,988$ & $63,768,365$ \\
\hline
\end{tabular}

Awards

\begin{tabular}{|c|c|c|c|c|}
\hline Organization & No. & Federal $(\$)$ & $\begin{array}{l}\text { Non-Federal } \\
\text { Funds (\$) }\end{array}$ & $\begin{array}{l}\text { Total } \\
\text { Funds (\$) }\end{array}$ \\
\hline $\begin{array}{l}\text { Academic } \\
\text { Institutions }\end{array}$ & 16 & $1,606,702$ & $1,783,028$ & $3,389,730$ \\
\hline $\begin{array}{l}\text { Non-Federal } \\
\text { Government }\end{array}$ & 1 & 156,625 & 193,375 & 350,000 \\
\hline Private & 0 & 0 & 0 & 0 \\
\hline Total & 17 & $1,763,327$ & $1,976,403$ & $3,739,730$ \\
\hline
\end{tabular}




\section{SECTIONI}

PROJECT SUMMARIES

FISCAL YEAR 1992 GRANTS 
BIOLOGICAL SCIENCES 


\section{PROJECT INFORMATION}

GRANT NUMBER:

PROJECT TITLE:
$14-08-0001-G 2261$

Detection of Hepatitis A and Norwalk Viruses by Polymerase Chain Reaction After Exposure to Water Disinfectants and Its Relationship to Virus Infectivity

PERFORMING ORGANIZATION: University of California at Irvine

PRINCIPAL INVESTIGATOR: R. De Leon

DURATION:

September 1992 to September 1994

\section{PROJECT DESCRIPTION}

\section{Identification of the Water-Related Problems.}

Waterborne outbreaks of acute viral gastroenteritis have been caused by contaminated ground water and drinking water. The presence of enteric viruses in source waters is a public health concern. Bacterial indicators of fecal contamination, such as total and fecal coliforms and $\underline{E}$. coli, are inadequate because they don't survive as well in the environment and are removed more efficiently in water treatment processes than are enteric viruses. Routine monitoring of human enteric viruses has not been feasible due to the costly and time consuming cell culture assays or lack of a cell culture assay, as in the case of Norwalk virus. Experimental methods based on nucleic acid hybridization are more rapid, practical, and cost effective detection methods for human enteric viral pathogens in water, but the data obtained are difficult to interpret. The relationship between virus detection by molecular techniques and virus viability, as determined by cell culture, needs to be directly addressed.

\section{Contribution to the Problem Solution.}

The U.S. Environmental Protection Agency has recently promulgated regulations requiring mandatory disinfection of all ground-water sources and filtration and disinfection of all surface water sources. Because these regulations emphasize disinfection to control health-related pathogens in drinking water, there are pressing needs to identify effective disinfectants, disinfection conditions, and methods to determine disinfection efficiencies for enteric viruses. 


\section{Objectives.}

The overall objective of this research is to determine if methods based on reverse trancriptase-polymerase chain reaction (RT-PCR) amplification and gene probes are a reliable approach for virus detection in water, and if they provide comparable information concerning virus viability or infectivity to cell cultures after exposure to chemical disinfectants or prolonged exposure (survival) in the environment.

\section{Approach.}

This hypothesis will be tested by comparing, in a model system, the detection of hepatitis A virus, polio virus, and Norwalk virus by a previously developed reverse trancriptase-polymerase chain reaction method, and by conventional cell culture after exposure to the disinfectants' chlorine, monochloramines, chlorine dioxide, ozone and UV light, or after prolonged exposure (survival) of virus seeded into samples of surface and ground water. The two methods will also be compared in field studies with wastewater effluents, and surface or ground water used as source water. Alternative RT-PCR approaches will be developed, if necessary, to increase the correspondence of virus detection by RT-PCR and by cell culture assays. 


\section{PROJECT INFORMATION}

GRANT NUMBER:

PROJECT TITLE:
14-08-0001-G2262

Biotic and Abiotic Weathering of Aquifer Rock

PERFORMING ORGANIZATION: Rensselaer Polytechnic Institute

PRINCIPAL INVESTIGATORS: $\quad$ F. Spear and H. Enrlich

DURATION:

August 1992 to August 1995

\section{PROJECT DESCRIPTION}

\section{Identification of the Water-Related Problems.}

The transport of toxic contaminants in ground-water supplies is a major problem as pure, fresh water becomes increasingly scare. A very promising approach to remediating this problem is the use of microorganisms. Microorganisms are known to affect the geochemistry of natural waters and to influence the transport and/or degradation of organic and inorganic contaminants in natural aquifers. These well documented effects typically involve some form of interactions between the microorganisms, the water and the material carried by the water. Not at all well understood is what, if any, effect microorganisms may have on the properties of the aquifer rock itself and whether this effect is a substantial contributor to the geochemistry of the water. In particular, it is not known whether microorganisms can affect the rate of weathering of aquifer material to any appreciable extent, especially in polluted aquifers, and, if they can, to what extent this will modify the chemistry of the waters.

\section{Contribution to the Problem Solution.}

Identification of microorganisms capable of enhancing the rate of weathering of aquifer material may lead to a valuable new method for the remediation or containment of toxic contaminants in ground water. This research is a first step towards quantifying the effects of microorganisms on aquifer modification by studying weathering of a common aquifer material, feldspar, in the presence of microorganisms. 


\section{Objectives.}

The objectives of this research are to:

(a) measure the rate of dissolution of alkali feldspar in the presence of a variety of different microorganisms;

(b) identify microbial varieties that significantly enhance weathering rates;

(c) characterize the effect of environmental factors (pristine versus polluted) on microbial enhancement of weathering;

(d) determine the mechanism(s) by which microbes accelerate the weathering rates; and

(e) analyze the properties of the residual (altered) feldspar to characterize its capacity for retardation of pollutant migraters.

\section{Approach.}

Batch and flow-through experiments using a variety of microorganisms and a variety of aqueous media will be used to measure the rate of feldspar weathering. Rates will be monitored by analysis of solution composition as a function of time. The physical characteristics of the altered feldspar will be examined using a variety of surface sensitive analytical techniques such as scanning electron microscopy, X-ray photoelectron spectroscopy, Rutherford backscattering, and secondary ion mass spectrometry. These techniques will permit examination of surface roughness, depth of compositional alteration, and production of secondary minerals. 
CLIMATEAND HYDROLOGIC PROCESSES 


\section{PROJECT INFORMATION}

GRANT NUMBER:

PROJECT TITLE:
$14-08-0001-G 2266$

Advection-Aridity Approach for Routine Evaporation Estimation and Subsurface Transport Simulation

PERFORMING ORGANIZATION: University of California at Davis

PRINCIPAL INVESTIGATOR: $\quad$ M. Parlange

DURATION:

August 1992 to July 1995

\section{PROJECT DESCRIPTION}

\section{Identification of the Water-Related Problems.}

Sixty to seventy percent of precipitation over land surfaces is evaporated, so that in hydrology it is crucial to accurately estimate evaporation, for example, when forecasting floods and droughts. It is also well recognized that accurate evaporation models are perhaps the most important component of climatic models at the global scale. However, in hydrology and climatology there is no agreement on how to model or calculate evaporation from any given region. The general land-surface models which have been developed recently have a detailed vertical parameterization of the soil, vegetation, and atmospheric surface layer. These detailed land-surface models are useful in studying climate change feedback in simulation studies. However, these models are difficult to apply to routine evaporation estimation since all the parameter inputs cannot be easily measured at the necessary spatial and temporal scales. We propose to extend, based on an intensive field experimentation program, an advectionaridity evaporation model which calculates evaporation over short time intervals ( $<1$ hour). The main advantage of this approach is that information related to some surface resistance parameterization is not required because the model relies only on atmospheric parameters. To date, the advectionaridity approach has been used only in the bare soil case. The next important step is to extend and evaluate its application to vegetated surfaces.

Experiments to evaluate the model will be carried out at Davis, California using different types of vegetative canopies. The advection-aridity theory also will be used to determine the effectiveness of linking flux estimates with a general physical model of soil water and heat transport.

\section{Contribution to the Problem Solution.}

Several important contributions would result: (1) the first continuous moisture and temperature measurements of subsurface soil over short time intervals 
(30 minutes) with simultaneous measurements of atmospheric properties and surface fluxes of water vapor, heat, and momentum; (2) improved understanding of the feasibility of applying the advection-aridity model for routine estimation of evaporation from any land surface; and (3) analysis of a detailed subsurface model of heat and mass transport with a root extraction model where the land-air flux boundary condition is given by advection-aridity.

\section{Objectives.}

The objectives of this research are to:

(a) concurrently measure soil and atmospheric profiles of moisture and temperature, fluxes of sensible heat, momentum and water vapor for vegetated and non-vegetated surfaces;

(b) test the reliability of the advection-aridity model for estimating evaporation under various conditions of advection, stability, and surface aridity; and

(c) determine the effectiveness of linking the advection-aridity flux estimates with a general physical model of soil water and heat transport.

\section{Approach.}

We plan to carry out evaporation measurements at the Davis experimental site for different vegetation and soil moisture conditions. The experiment will include continuous thirty minute measurements with two large lysimeters, eddy correlation flux equipment, atmospheric profile instrumentation, an automated Time Domain Reflectometer system for soil moisture measurement, soil temperature probes and heat flux plates, and radiation equipment. Plant properties such as leaf area index and root distribution will be regularly sampled. The soil and plant measurements will be used to test a model of coupled heat and mass transfer with plant root-water uptake model. 


\section{PROJECT INFORMATION}

GRANT NUMBER:

PROJECT TITLE:
$14-08-0001-G 2267$

Predictability and Variability of Climate and Hydrology: Inferences from Great Salt Lake Dynamics

PERFORMING ORGANIZATION: Utah State University

PRINCIPAL INVESTIGATOR: U. Lall

DURATION:

September 1992 to August 1994

PROJECTDESCRIPTION

\section{Identification of the Water-Related Problems.}

Projected global climate changes may lead to hydrologic imbalances with severe impacts in the arid western United States. Variations of regional climate are important not only geographically but over long time scales. There is a need to assess the impact of changes in climate on hydrologic extremes, for example floods and droughts, as well as the inter-annual and seasonal variability of basin yields. Water resource management would be more efficient if the onset, severity, and cessation of impending droughts or wet periods could be more accurately predicted. A case in point is the "surprising" recent 5 year rise of the Great Salt Lake to record levels, the coincidental installation of pumps (in year 5) for lake level control, and rapid lake recession from natural causes.

\section{Contribution to the Problem Solution.}

In the arid west, floods and drought are related to soil moisture, to snow rather than to rainfall. Persistence of wet and dry spells is observed across the region, and connection to large scale climatic anomalies are indicated. Our preliminary work with Great Salt Lake basin hydro-climatic data indicates that multiple, climatic regimes may exist. Inter-annual climatic variability may be described through transitions between these regimes. We propose to identify and relate these regimes to causative factors or identifiable climatic patterns, and to characterize the nature of the transitions. The predictability of hydrologic extremes will be improved through (1) identification of conditions leading to the initiation, persistence or cessation of a hydrologic or climatic anomaly, (2) prediction of the severity and duration of different hydrologic regimes, and (3) a dynamic decomposition of spatially aggregated hydrologic variability into components related to variability in climate and the variability of basin conditions. 


\section{Objectives.}

The objectives of this research are to:

a. develop methods to analyze climatic and hydrologic time series to identify different regimes of behavior and long term predictability (or characteristic time scales of variation);

b. develop procedures for analyzing the dynamic interaction of climatic and hydrologic variability at basin or larger spatial scales and at time scales consistent with climatic transitions. Quantify unforced and forced basin water balance variability, as well as sensitivity to initial basin conditions;

c. develop "residence time" distributions for different regimes, and describe the properties of onset, severity, and duration of climatic and hydrologic anomalies in a basin/region; and

d. apply the techniques developed to the Great Salt Lake Basin and assess regional implications.

\section{Approach.}

Closed basin lakes exist where long term evaporation exceeds precipitation, and they are very sensitive to climatic variability. Lake volume changes in time represent a spatial integration of basin hydrology (and lake evaporation). Lake volumes represent a space-time integration of basin and lake response to climatic forcing. Lake evaporation depends on climatic conditions, as well as lake salinity (from 70 percent of freshwater evaporation to $<5$ percent) and volume. The lake volume-salinity relation is hysteretic. In a wet period, lake area increases, salinity decreases, evaporation increases, and the rate of lake volume increase is bounded. Conversely, in a dry period, the rate of lake volume decrease is bounded. Internal mechanisms, in addition to climatic forcing and inflows from the basin, thus influence lake dynamics. A physical water, energy and salt balance model of the Great Salt Lake shall be developed to describe the internal dynamics of the lake. The dynamics of the aggregated basin hydrologic processes, their variability and relation to a specified, dynamic climate forcing, then can be recovered. State space representation of the coupled dynamic water and energy balances of the regional climate, in the Great Salt Lake basin, shall also be looked at. These models will be used for quantitative and qualitative insights related to the objectives stated.

Nonparametic discrimination methods will be used to identify operative climatic regimes and their relationship to known climatic anomalies and boundary conditions. 


\section{PROJECT INFORMATION}

GRANT NUMBER:

PROJECT TITLE:
$14-08-0001-G 2268$

Transient Response of Upland Watersheds to Storm Events: A Comparative Study

PERFORMING ORGANIZATION: University of California at Berkeley

PRINCIPAL INVESTIGATOR: $\quad$ T. Narasimhan

DURATION:

September 1992 to September 1995

\section{PROJECTDESCRIPTION}

\section{Identification of the Water-Related Problems.}

In response to rain events, upland watersheds generate runoff through a variety of surface and subsurface pathways. These flow paths control a number of processes including flooding, slope instability, channel incision, and increased sediment and solute discharge to streams and rivers. Past investigations of rainfall-runoff relationships have shown that the coupling between individual storm events and runoff is highly transient and is influenced by flow through macropore horizons, saprolite (weathered bedrock), and bedrock. Further, the interaction between these pathways is highly dependent on seasonally variable antecedent moisture conditions in the unsaturated zone. Although the importance of the individual pathways has been established by previous workers, a gap exists in our understanding of how subsurface flow paths interact to convey storm runoff and affect pore pressure distributions. The time-scale over which the different flow paths respond is also unknown. A need exists to formulate a physical framework in which fluid flow, pore-pressure evolution, erosion, and solute transport are integrated to get a better understanding of upland watershed response.

\section{Contribution to the Problem Solution.}

The results of this research will enhance our ability to estimate stream flow, sediment generation, channel erosion, and water quality in upland watersheds. By analyzing all of the subsurface flow systems in an integrated, dynamic manner, we hope to provide new information on the watershed processes controlling runoff production and pore pressure development that can lead to slope failure. It is felt that the proposed comparative approach will lead to observations of a more general nature and applicability. 


\section{Objectives.}

The objectives of this research include:

a. investigation of the time-scale of response (minutes, hours, or days) of transient flow through the soil matrix, macropores, and bedrock.

Estimation of the hydraulic diversity of each of these pathways;

b. identification of the different conditions under which each of these features may dominate rainfall-runoff and rainfall-pore pressure linkages;

c. employment of a combination of field observations and simulations (using a physically-based numerical model) from multiple watersheds as the basic methodology of investigation;

d. constraint of the physically-based model by analyzing water chemistry data on a similar spatial/temporal scale. In other words, chemical data will be used to supplement the physical data and may help reduce the nonuniqueness of the physically-based interpretations;

e. instrument and characterize bedrock flow systems at selected field sites for comparison with numerical simulations;

f. identify critical topographic and geologic parameters and climatic conditions that govern the partitioning of runoff between different subsurface flow paths; and

g. based on the above, attempt to identify broad criteria that can be used to recognize the relative importance of the various flow paths in a given water shed.

\section{Approach.}

The approach is to combine field observations on dynamic changes in fluid pressure, stream flow, and water chemistry with physically inspired mathematical models capable of simulating interacting heterogeneous components under highly transient conditions of flow. Comparative data will be obtained on different watersheds through active collaboration with U.S. Geological Survey and the U.S. Forest Service research groups. Concurrence for this research collaboration has already been obtained. Numerical models needed for the study have already been developed by this investigator over the past many years through other research ventures. 


\section{PROJECT INFORMATION}

GRANT NUMBER:

PROJECT TITLE:
$14-08-0001-G 2271$

The Role of Turbulent Shear Stresses on Pavement Formation and Bedload Motion in Gravel Bed Streams

PERFORMING ORGANIZATION: Virginia Polytechnic Institute and State University

PRINCIPAL INVESTIGATORS: $\quad$ P. Diplas and C. Dancey

DURATION: $\quad$ September 1992 to September 1995

\section{PROSECT DESCRIPTION}

\section{Identification of the Water-Related Problems.}

The bed material of gravel streams is typically characterized by a wide range of grain sizes. Observations of natural gravel rivers during low flows indicate the presence of a surface bed layer that is considerably coarser than the subsurface material. Knowledge of the formation and maintenance of this coarser layer is important for determining the frictional characteristics of gravel beds, for calculating bedload transport rates of poorly sorted sediments, for explaining the fining of bed material along a stream, and for monitoring the quality of spawning grounds. The evolution of the grain size composition of this surface layer during high flows is especially important for the design of flood protection schemes and for predicting the local scour around bridge piers. The principal water related problems to be addressed in this research is to better understand how pavement layers form and their role on bedload motion.

\section{Centribution to the Problem Solution.}

This research should improve our ability to predict the composition of the pavement layer during different flow conditions. It should also provide us with methods for calculating accurately the quantity and size distribution of the bedload material for flow events ranging from near threshold conditions to extreme floods.

\section{Objectives.}

The objective of this study is to determine the role of instantaneous turbulent shear stresses on the formation of pavement layers. The increased availability of the coarser grains in the pavement tends to partially compensate for the 
decreased mobility of these grains. In this study, the effect of turbulent bursting and particle availability on the quantity and composition of the transported sediment will be assessed. The influence of these two parameters on bedload motion has never been examined before. This research is clearly aimed at improving our understanding of the fundamental mechanisms involved in the dynamic interaction of the flow field and the bed material. As a result better predictions of the river response to given flow conditions, or known changes of them, should be expected.

\section{Approach.}

Laser Doppler anemometry and video recording with image processing will be used to study the structure of turbulent boundary layers over rough surfaces. Spherical particles with the same diameter but with different densities will be used to isolate the role of particle availability on its entrainment. The continuous monitoring of the channel bed will provide information about the response of the pavement layer to changing flow conditions. The approach used in this study has several novel elements and is expected to elucidate our understanding of fluid flow-sediment interaction. 
ENGINEERING 


\section{PROJECT INFORMATION}

GRANT NUMBER:

PROIECT TITLE:
$14-08-0001-G 2263$

Remediation of Acid Drainage Through Surface Coating of Fe-Sulfides

PERFORMING ORGANIZATION: University of Kentucky

PRINCIPAL INVESTIGATOR: V. Evangelou

DURATION:

September 1992 to September 1994

\section{PROJECTDESCRIPTION}

\section{Identification of the Water-Related Problems.}

The principal problem addressed in this proposed project is the production of acidic drainage (solutions of low $\mathrm{pH}$ that are high in heavy metals) from geologic strata containing Fe-sulfides. Such geologic strata are commonly associated with various ores or energy fossils of great economic and strategic importance. The ores and/or fossils associated with Fe-sulfides are distributed throughout the United States. Examples include, cooper, lead, zinc, uranium, gold, silver, coal, and lignite. Exposure of these metal-sulfides to atmospheric $\mathrm{O}_{2}$ and water, either through natural or man made processes, leads to oxidation and contamination of ground and surface waters with heavy metals as well as arsenic.

A recent survey carried out by the Oak Ridge National Laboratory revealed that more than 50 percent of all surface water bodies in the Eastern United States coal fields with dangerously low pH can attribute this condition to acid drainage. Other surveys have shown that more than 8000 miles of streams in the eastern coal fields are contaminated by acid mine drainage.

\section{Contribution to the Problem Solution.}

The research will contribute to the solution of the above problem through the application of a new remediation technology. It involves the formation of a highly stable ferric phosphate coating on the surface of pure Fe-sulfides minerals. This coating has been shown to render pure Fe-sulfides (pyrite) inert.

\section{Objectives.}

The objectives of this research are to:

a. establish procedures and reagent concentration to form stable 
Fe-sulfide oxidation inhibiting ferric phosphate coatings in geologic strata;

b. test the role of surface chemical composition, organic content and $\mathrm{pH}$ (surface chemistry of geologic material) on the formation and specificity of stable Fe-sulfide oxidation inhibiting ferric phosphate coatings;

c. test the role of interstitial solution composition of geologic material containing pyrite on the formation of stable Fe-sulfide oxidation inhibiting ferric phosphate coatings; and

d. demonstrate the technology in long laboratory columns and in the open environment employing large barrels.

\section{Approach.}

Currently, acid metallic drainage produced by Fe-sulfide oxidation is controlled by several approaches: (1) application of limestone or rock phosphate, (2) application of bactericides, and (3) creation of fully anoxic environments by using clay liners, plastic liners, asphalt, etc. The first two acid drainage remediation technologies have a short life span, and the third technology can be cost prohibitive as well as ineffective over time due to deterioration.

Our acid drainage remediation technology involves specific targeting of $\mathrm{Fe}$ sulfide minerals and coating them with Ferric-phosphate (strengite), a highly acid stable mineral that renders Fe-sulfide inert. This coating is believed to be permanent. It is cost effective since it only involves readily available materials and covers the surface of the Fe-sulfide. Furthermore, the coating solution can be applied to any geologic material that possesses hydraulic properties, thus no physical disturbance of land is necessary. 


\section{PROJECT INFORMATION}

GRANT NUMBER:

PROJECT TITLE:
$14-08-0001-G 2264$

Innovative Alternative for Sediment Removal from Reservoirs: Phase I

PERFORMING ORGANIZATION: University of Nebraska

PRINCIPAL INVESTIGATOR: R. Hotchkiss

DURATION:

August 1992 to July 1994

\section{PROJECTDESCRIPTION}

\section{Identification of the Water-Related Problems.}

Surface water impoundments induce sediment deposition and reduce downstream sediment supply. This change in the sediment balance has a profound and long-lasting effect for reaches upstream from the reservoir, within the reservoir, and downstream. Sediment deposition in the upper reaches of the reservoir raises the water surface and extends the influence of the reservoir upstream. This results in higher ground-water levels that can displace farm production and affect entire communities. Deposition within the impoundment body reduces the storage available for flood control, irrigation, power production, and recreation. The reductions in sediment supply downstream result in streambed scour that affects water intake structures and results in lower local ground-water levels. Downstream sediment depletion may also trigger changes in channel morphology that may then change fish and waterfowl habitats.

Three major challenges exist for removing sediment from reservoirs: (1) find an economical and environmentally acceptable method for sediment removal, (2) address regulatory issues that may apply to sediment removal and transport downstream, and (3) deal with the larger social impacts of changing downstream sediment regimes towards pre-reservoir conditions.

\section{Contribution to the Problem Solution.}

The proposed research will focus on the first two challenges mentioned above. The research will test details of an innovative way of removing sediment from reservoirs that should prove to be economically and environmentally sound. If the tests are successful, the results will be used in a future project to install the sediment removal system in a Nebraska reservoir. The system would extend reservoir life, increase storage capacity, protect the environment, and begin to restore downstream sediment regimes and appurtenant habitats. The 
technology could then be applied to reservoirs around the country. As a parallel effort to testing the new method, the research will identify what regulations may affect such activities, as an example for similar projects elsewhere in the United States.

\section{Objectives.}

The objectives of this research are to:

a. design a sediment removal system for Spencer dam in Nebraska that employs a submerged pipeline system to transport sediment downstream;

b. construct physically-scaled laboratory models of the reservoir and pipe intake structure to insure that sediment is moved into the pipeline system efficiently;

c. identify all applicable regulations for such activities in preparation for future installation (installation is not a part of this proposal); and

d. disseminate results to illustrate the technology and the legal issues involved in restoring the sediment balance in river reaches affected by reservoirs.

\section{Approach.}

The removal system consists of a submerged pipe extended upstream through a dam and extending along the bottom of the reservoir to deposited sediments. Water and sediment will flow into the pipe due to the potential energy created by the difference in upstream and downstream water levels. The method requires relatively small volumes of water compared to alternate methods of sediment removal. Sediment releases to downstream waters can be carefully controlled to minimize adverse environmental impacts. This approach, while not new, is untested in the United States at a large scale. 


\section{PROJECT INFORMATION}

GRANT NUMBER:

PROJECT TITLE:

PERFORMING ORGANIZATION: Utah State University

PRINCIPAL INVESTIGATOR:

DURATION:
$14-08-0001-G 2265$

Non-Parametric Stochastic Simulation of Stream Flow in the Colorado River

D. Tarboton

September 1992 to August 1994

\section{PROSECTDESCRIPTION}

1. Identification of the Water-Related Problems.

In the design and operation of water-resources systems, engineers have always recognized the variability and uncertainty of the hydrologic inputs. Stream flow is a highly nonlinear and unpredictable process. Water supply and management agencies are faced with the unavoidable decisions of designing and managing water resources systems in the face of this uncertainty and need carefully synthesized or forecast stream flows to properly plan reservoir operations and system expansions to meet future demands. This is the case for many river systems. One river system crucial to water supply in the arid southwestern United States is the Colorado. To develop optimal operating rules and control strategies for complex systems, synthetic flow that reproduces the important statistical properties of past stream flow is required. Forecasts of stream flow also need to be conditioned on the current state of the hydrologic system.

\section{Contribution to the Problem Solution.}

The research will use the full multivariate probability distributions describing stream flow to develop reliable and realistic stream flow simulations and forecasts. The investigator will apply these techniques to the Colorado River and use robust non-parametric techniques to estimate the required probability distributions based only on the data. These techniques are relatively new in the statistical literature and have only had limited application in hydrology. Procedures currently used are usually linear in nature and use particular distributions to parameterize stream flow. The choice of distributions is arbitrary, or from a set (usually small) of known distributions, often with no physical reason for selection. By working with the full distributions, rather than the first two moments (mean, variance, and correlation) which effectively linearize the full distributions, we will account for non-linearity. Thus, we can expect to directly reproduce observed persistence in stream flow and better 
characterize the extreme events, such as droughts and floods, that are often the most critical hydrologically.

\section{Objectives.}

The primary objective is to develop better methods for the simulation and forecasting of hydrologic processes, in particular stream flow, based on observed data. We propose to use non-parametric procedures to limit, as much as possible, arbitrary assumptions imposed by model structure and be guided only by information in the observed data. The research methods should capture some of the non-linearity and inhomogeneity present in stream flow that cannot be modeled using conventional linear approaches.

\section{Approach.}

The Colorado River system will be used as a convenient and demanding case study for the development of these techniques. Unimpaired stream flows at 29 source inflow sites have been estimated by the Bureau of Reclamation and are used with their Colorado River System Model to plan and evaluate options for the management of the Colorado. These stream flows will be used in kernel based procedures to estimate the multivariate probability distributions required for simulation. Ultimate validation and verification will be by comparison of our results to results obtained using currently accepted parametric procedures as encoded in a state of the art stochastic hydrology package. A set of performance statistics for stream flow synthesis that are relevant to reservoir operation will be assembled and used for comparing parametric and nonparametric approaches. 
GROUND-WATER FLOW AND TRANSPORT 


\section{PROJECT INFORMATION}

GRANT NUMBER:

PROJECT TITLE:
$14-08-0001-G 2257$

Determination of Hydraulic Properties

of Unsaturated Soil Using Point

Application of Water

PERFORMING ORGANIZATION: University of Arizona

PRINCIPAL INVESTIGATORS: A. Warrick and M. Yitayew

DURATION: $\quad$ September 1992 to September 1995

\section{PROJECT DESCRIPTION}

\section{Identification of the Water-Related Problems.}

Ground-water recharge and the transport of pollutants are strongly dependent upon the hydraulic properties of the unsaturated soil. This is true both at the soil surface and throughout the vadose zone. The unsaturated depths are generally deeper in arid zones, but the processes apply to humid regions as well, indeed to all parts of the nation. Reliable predictions of travel time and flux densities are intimately related to the quality of the characterization of the unsaturated flow properties. These include the soil water characteristic relationships (moisture content-pressure curves) and the unsaturated hydraulic conductivity function. Available techniques are tedious and subject to a high degree of experimental variability. The most common methodologies emphasize laboratory measurements of "undisturbed" soil cores or through soil that has been repacked. For lack of better information and because of difficulty in making measurements, decisions are made on incomplete or borrowed data.

\section{Contribution to the Problem Solution.}

This research addresses methodology for both measurements and analyses based on devices for infiltration from point and disc sources. The devices will make measurements in situ under carefully controlled conditions--either a constant flux or a constant tension source. The proposed methods will advance the techniques with the idea of making the measurements easier, cheaper, and more reliable. Also, the interpretation and data manipulation will be optimized to extract meaningful information, including the appropriate hydraulic parameters. 


\section{Objectives.}

The objectives of this research are to:

a. determine hydraulic properties of unsaturated soil based on parameter optimization and in-situ measurements from point source applications and disc-tension infiltrometers; and

b. design and construct devices to evaluate hydraulic properties of unsaturated soil based on point and disc source application.

\section{Approach.}

The research involves measurements, design, and modeling. The beginning experiments will include measurements of the soil water regime near an prototype disc-tension infiltrometer and around constant flow drippers. The infiltrometer will provide flow rates as a function of time, and the soil measurements will provide additional information for the soil response. The constant-flow dripper gives information, both in terms of the wetting pattern on the soil surface and water content on the soil surface, but the soil measurements will provide additional information. Models will be used to extract a maximum amount of information from the measurements. Existing methodology for the disc-tension infiltrometer and on general parameter estimation methods using one-dimensional systems will be included. Additionally, scaling techniques will be vigorously pursued in order that computations be manageable. 


\section{PROJECT INFORMATION}

GRANT NUMBER:

PROJECT TITLE:
14-08-0001-G2258

Characterization of the Fate and Transport of Volatile Organic Compounds in Porous Media Under Unsaturated Conditions

PERFORMING ORGANIZATION: University of Arizona

PRINCIPAL INVESTIGATOR: T. Yeh

DURATION:

September 1992 to September 1994

\section{PROJECTDESCRIPTION}

1. Identification of the Water-Related Problems.

Volatile organic compounds (VOCs), particularly chlorinated hydrocarbon solvents and petroleum products, found in the subsurface environment at Superfund sites in the United States are among the most ubiquitous contaminants of our ground-water reservoirs. Many of these organic contaminants are toxic to humans, other animals, and plants at very low concentrations; a small amount can pose a serious long-term threat to the quality of ground water.

The organic contaminants generally enter the ground-water reservoirs through the vadose zone due to chemical spills and leaks from waste burials and storage tanks. During migration to the water table, some of the organic liquids trapped in the vadose zone at residual saturation levels will be released into the vapor phase. Vapors that are less dense than air will rise toward the ground surface, whereas those more dense than air will sink toward the capillary fringe. Because of their significant gas-water partitioning ability and high toxicity, vapors near the water table will dissolve and can lead to increased contamination of ground water.

Gas-phase processes are especially important in semi-arid areas such as Arizona and California where precipitation is insignificant and the water table is deep. Gas-phase transport of contaminants volatilizing from trapped organic liquids in the vadose zone has been suggested as the major mechanism of ground-water contamination by VOCs in such areas. 


\section{Contribution to the Problem Solution.}

This research will provide a relatively simple way to determine hydraulic conductivity and air permeability in media under variable unsaturated and saturated conditions. Success of this technique will lead to advances in measurement technology for field conditions. An automatic inverse procedure to be developed will be a useful tool for estimating dispersive and mass transfer parameters under both steady- and transient-flow and transport conditions. The analysis of the dependence of dispersity and mass transfer coefficient on moisture content and hysteresis effects may lead to new findings on understanding of $\mathrm{VOC}$ migration in both unsaturated and saturated geologic media.

\section{Objectives.}

The primary objective of this research is to investigate dispersive properties of soils for both water- and gas-phase solute and the mass transfer behavior of a VOC (trichloroethylene, TCE) under variable unsaturated and saturated conditions.

\section{Approach.}

To accomplish the objectives, three major research tasks will be conducted. Task 1 is to characterize hydraulic and pneumatic properties of two soils and to conduct solute and gas transport experiments in soil columns, using bromide solution, helium gas, and TCE gas under different soil moisture conditions during wetting and drying scenarios. Task 2 is to develop a numerical model and an automatic inverse procedure for estimating dispersive and mass transfer parameters for gas and liquid in unsaturated porous media. Task 3 is to analyze the dependence of the dispersive and mass transfer parameters on the soil moisture content and wetting-drying history. 
SOCIAL SCIENCES 


\section{PROJECT INFORMATION}

GRANT NUMBER:

PROJECT TITLE:
$14-08-0001-G 2253$

Using Water Banks to Promote More

Flexible Water Use

PERFORMING ORGANIZATION: University of Colorado

PRINCIPAL INVESTIGATOR: $\quad$ L. MacDonnell

DURATION: $\quad$ September 1992 to August 1994

\section{PROJECTDESCRIPTION}

\section{Identification of the Water-Related Problems.}

With rights to use the water resources of the western States essentially fully allocated, new uses will depend increasingly on reallocation of existing supplies. Water transfers and exchanges, both permanent and temporary, are an important means of accomplishing this reallocation. The use of permanent transfers has now been well documented and analyzed as a result of a number of recent studies. Temporary transfers, particularly those occurring under various water banking arrangements, have received far less attention. The use of water banks to meet short-term water needs has been growing. A major example is the water bank established in 1991, during California's fifth consecutive year of drought.

The term "water banking" has been applied to a variety of arrangements in which water allocations established for one use are made available for a different use on a short-term basis. Water banks appear to facilitate more flexible use of limited water supplies and may be especially valuable in periods of drought. Various types of banking arrangements are now in use and others have been proposed. Yet, the water bank concept is not well understood and is used to describe very different activities. There is little research concerning water banks, particularly work that evaluates the structure, operation, and performance of these arrangements.

\section{Contribution to the Problem Solution.}

This project will help fill this void by providing a comprehensive analysis of water banking. It will include a much-needed conceptual treatment and will involve detailed examination of several existing banks. It will provide estimates of the benefits and costs of these banks and will systematically examine a number of important issues presented by use of banks, including forfeiture and third party effects. It will identify effective features of banks and will propose banking 
arrangements as well as necessary changes in law to facilitate such arrangements.

\section{Objectives.}

Project objectives are to provide conceptual and practical clarity to the water banking idea; to evaluate the performance of selected water banks from an economic, legal, and administrative perspective; to determine the conditions under which water banks result in net benefits; to develop water bank designs; and to recommend changes in state and Federal law that would facilitate the use of water banks.

\section{Aporoach.}

The research will identify and categorize existing and proposed water banks and bank-like arrangements. This effort will develop economic models for their evaluation. This effort will use detailed case studies to perform our evaluation. This effort will apply our findings to the design of water banking arrangements in two situations where the use of banks has been proposed. 


\section{PROJECT INFORMATION}

GRANT NUMBER:

PROSECT TITLE:
14-08-0001-G2254

An Analysis of Water Quality Enforcement Strategies and Their Effectiveness in Achieving Water Quality Standards

PERFORMING ORGANIZATION: West Virginia University

PRINCIPAL INVESTIGATOR: S. Hunter

DURATION:

August 1992 to July 1994

\section{PROJECT DESCRIPTION}

\section{Identification of the Water-Related Problems.}

The evaluation of water quality enforcement activities in the United States has relied on either data on the percentage of the National Pollution Discharge Elimination System permittees in significant non-compliance, or on the number and type of enforcement actions taken. Both indicators measure actions rather than outcomes, and therefore are problematic at least. Previous research has uncovered inconsistencies in the reporting of enforcement action by states and the Environmental Protection Agency (EPA) reports of state enforcement actions. Analysis of EPA records has also uncovered regional and longitudinal differences in enforcement actions that reflect differences in enforcement strategies, reporting of actions, and social, economic, and political pressures on regulators. Attempts to evaluate state and Federal efforts may be seriously distorted by inaccurate data, and, even when accurate, differences in enforcement activities may or may not lead to differences in water quality outcomes. Because no clear indicators of water quality exist, no accurate measures of regulatory effectiveness have been developed.

\section{Contribution to the Problem Solution.}

The analysis of factors affecting enforcement strategies will aid in the development of realistic enforcement standards. Equally important, the analysis of performance indicators used to evaluate enforcement actions can improve evaluations for a variety of regulatory policies; and the analysis of reporting discrepancies can improve communications between EPA and local water pollution control offices. 


\section{Objectives.}

Research objectives are to determine whether enforcement styles affect outcomes with regard to water quality and whether reporting difference between states and the EPA reflect serious philosophical differences and/or reporting problems. A third objective is to develop an explanatory model of the variables that affect water quality enforcement and outcomes.

\section{Approach.}

Personal, telephone, and mail interviews with EPA regional directors, water enforcement directors, and state water pollution control officials will be used to determine priorities, enforcement styles, environmental values, personal performance indicators, and local factors affecting enforcement in each state and region. State Quarterly Reports and other agency data will be used to determine the numbers and types of enforcement actions. A comparison with EPA records for identical time periods will allow an examination of discrepancies. Data on water quality will be obtained from as many sources as possible. Regression analysis will be used to measure the effect of each variable on water quality. 


\section{PROJECT INFORMATION}

GRANT NUMBER:

PROUECT TITLE:
14-08-0001-G2255

Negotiated Indian Water Rights

Settlements: The Efficacy of

Negotiation as a Dispute Resolution

Strategy

PERFORMING ORGANIZATION: University of Utah

PRINCIPAL INVESTIGATOR: $\quad$ D. McCool

DURATION: $\quad$ August 1992 to July 1995

PROJECTDESCRIPTION

1. Identification of the Water-Related Problems.

The doctrine of federally reserved water rights, established in the landmark case of Winters versus United States (207 U.S. 564), initiated an intense conflict over western water that continues to this day. The problem is how to settle disputes over Indian reserved water rights so that the solution results in substantive, equitable, and culturally sensitive benefits for tribes without causing undue hardships to non-Indian water users.

\section{Contribution to the Problem Solution.}

In recent years, the strategy of negotiated settlements has emerged as the preferred method of resolving water disputes between tribes and non-Indians. Proponents of negotiation claim a host of advantages that are unique to negotiation as a conflict resolution strategy. Since 1980, ten tribes have signed negotiated settlements, and at least twenty more are in progress. However, there has never been a comprehensive evaluation of the negotiation/ settlement strategy to assess whether it does in fact result in the claimed advantages. This study will analyze the strategy of negotiated water settlements to determine its efficacy as a dispute resolution process compared to other possible dispute resolution strategies.

\section{Objectives.}

This study will analyze negotiated Indian water rights settlements relative to other forms of dispute resolution, such as litigation and comprehensive legislation, in order to measure and evaluate the relative efficacy of settlements to resolve Indian-non-Indian conflicts over water. 


\section{Approach.}

The first phase of the project will examine all Indian water settlements, and other dispute resolution strategies, in order to gain a comprehensive perspective on the strategy of negotiation and its relative outcomes. The second phase will consist of an in-depth on-site analysis of five reservations that have signed settlements. The research will utilize data on water rights, storage, and use; budgetary data; interviews; and primary and secondary sources of information. The third phase will update the research. 


\section{PROJECT INFORMATION}

GRANT NUMBER:

PROSECT TITLE:
14-08-0001-G2256

Aggregation, Declining Block Prices, and Urban Water Demand in Humid Areas

PERFORMING ORGANIZATION: University of Illinois

PRINCIPAL INVESTIGATORS: J. Braden and D. Chicoine

DURATION:

August 1992 to August 1993

PROJECT DESCRIPTION

1. Identification of the Water-Related Problems.

The following issues need to be addressed to formulate better water use policy: (1) discrepancies between aggregate-level and household-level estimates of residential demand for water; (2) lack of knowledge about the behavioral effects of declining block rates prices, that are common in humid regions, as contrasted with the increasing block rate structures that are common in arid regions, where most studies of water demand have occurred;

(3) uncertainty about the effects of different water-use technologies on residential water demand in humid regions; and (4) lack of information on water demand relationships in midwestern cities.

\section{Contribution to the Problem Solution.}

The research will provide quantitative insights into the preceding issues. By so doing, it will provide a more solid foundation for water pricing policies intended to bring demand in line with water supply in the specific circumstances facing water utilities in humid areas.

\section{Objectives.}

The objectives of this research are to improve knowledge about urban water demand in humid regions and determine whether water demand relationships are affected by the use of aggregate-level and household-level observations on the same population, for different water use technologies, and for alternative specifications of the declining block rate price structure.

\section{Approach.}

This research will use econometric techniques to estimate water demand relations. The estimates will be based on unique data for twelve small- and 
medium-sized cities in Illinois. Those data include aggregate observations on residential water consumption and income, and nearly 15,000 observations on household-level water consumption, income, socioeconomic characteristics, and water-use technologies. 
WATER QUALITY 


\section{PROJECT INFORMATION}

GRANT NUMBER:

PROSECT TITLE:
$14-08-0001-G 2259$

Deep Production in Lakes: Effect on Nutrient Transport, Trace Metal Cycling and Paleolimnology

PERFORMING ORGANIZATION: Wisconsin Department of Natural Resources

PRINCIPAL INVESTIGATORS: J. Hurley, P. Garrison, D. Armstrong, and $M$. Shafer

DURATION:

September 1992 to January 1995.

\section{PROJECTDESCRIPTION}

\section{Identification of the Water-Related Problems.}

Water quality in lakes and reservoirs is intimately linked to the planktonic community. While representing an essential component of the food web, sustaining higher organisms, plankton are also associated with problems of nuisance blooms, oxygen depletion, toxin production, and transport of toxic chemicals into the food chain. Furthermore, desirable groups may be replaced by problem-producing forms through competition for limiting resources of light and nutrients. Thus, in order to manage and protect water quality, an understanding of the controls on plankton communities is essential.

\section{Contribution to the Problem Solution.}

The research will benefit water quality managers who require rapid turnover of information on biological and chemical characteristics of lakes. We expect to define sets of characteristics that may lead to deep production in stratified lakes. Our results from trace metal cycling studies will describe the effects of deep production on epilimnetic metals behavior and will help define sampling strategies for water quality assessment. Additionally, since sedimentary pigment stratigraphies are used to assess recent and historical changes in water quality conditions, we will assess the influence deep production exerts on pigment preservation in sediments.

\section{Objectives.}

The objectives of this research are to:

a. evaluate the importance of deep planktonic production to overall lake 
production and controlling water quality;

b. evaluate the effects of deep plankton on trace metal transport by comparing selected trace metals both within lakes and among lakes with differing particle types and differing redox characteristics;

c. examine the effects of deep production on phosphorus cycling; and

d. evaluate the effects of deep water production in controlling the pigment composition of sediments.

\section{Approach.}

The project will obtain detailed profiles from 10-15 stratified lakes in Wisconsin during maximum summer stratification (August-September). Lakes of contrasting deep planktonic populations (presence versus absence of phototrophic bacteria, yellow-brown versus blue-green algae, and so forth), trophic gradients (oligotrophic to eutrophic), geological character (hardwater versus softwater), and surface area (important for lake mixing) will provide possible contrasts.

During the second year, we will intensively study effects of deep production in two lakes. We most likely will choose Mirror Lake and a second contrasting lake. Mirror Lake is a mesotrophic lake that exhibits strong metalimnetic production of both phototrophic bacteria and blue-green algae. The second lake, chosen from the survey, will contrast with Mirror Lake, in that the lake will exhibit a less intense period of anoxia. Lakes will be sampled approximately every two to three weeks from ice-out to ice-cover to follow the development of the deep layer. Production estimates and field experiments will be designed to best evaluate the effects of deep production.

In the third year, we will continue our comparison of contrasting lake features to evaluate effects of deep production, by intensively studying a third lake. Measurements will be similar to those conducted during Year 2. The third lake will contain deep production that is not associated with anoxic conditions. 


\section{PROJECT INFORMATION}

GRANT NUMBER:

PROJECT TITLE:
$14-08-0001-G 2260$

Phosphorus Fourier Transform Nuclear Magnetic Resonance (FT-NMR) Analysis of Organic Phosphorus in the Hydrosphere

PERFORMING ORGANIZATION: University of Illinois

PRINCIPAL INVESTIGATOR: R. Minear

DURATION: $\quad$ September 1992 to September 1994

PROJECTDESCRIPTION

1. Identification of the Water-Related Problems.

Organic phosphorus generally represents the major source of available $P$ in most aquatic and terrestrial ecosystems. Although $P$ availability is frequently the principle limitation to inorganic carbon fixation and organic carbon mineralization, and $P$ is tightly conserved or retained within these ecosystems, the dynamics of organic $P$ mineralization and fixation in aquatic and terrestrial ecosystems is poorly understood. This is due to a lack of information on the chemical identity of organic phosphorus compounds in soils, sediments, and ground and surface waters. The difficulty in obtaining this information is due to the low concentration of organic phosphorous and also to the lack of analytical techniques that can readily identify these organic phosphorus species at such low concentrations and in complicated matrices.

\section{Contribution to the Problem Solution.}

This research will assist in a better understanding of the organic phosphorus cycle by (1) providing new tools and procedures for the isolation, identification, and characterization of organic phosphorus in the hydrosphere, (2) identifying and characterizing the organic phosphorus present in the different environmental compartments, (3) providing insight to the interaction between organic phosphorus and humic and fulvic acids, and finally (4) by determining the spacial and temporal distribution of organic phosphorus throughout the environment, which can aid in future modeling of the phosphorus cycle.

\section{Objectives.}

The objectives of this research are to:

a. develop non-ionic resin based extraction techniques for the isolation and 
recovery of dissolved organic phosphorus (DOP) from the hydrosphere;

b. identify and characterize organic phosphorus compounds in soils, sediments, and ground and surface waters using ${ }^{31} \mathrm{P}$ FT-NMR and high pressure liquid chromatography (HPLC):

c. develop the use of aqueous-soluble lanthanide shift reagents to aid in the ${ }^{31} \mathrm{P}$ FT-NMR identification and characterization of DOP;

d. characterize the interactions between DOP and dissolved organic carbon $(D O C)$ present in the hydrosphere; and

e. determine the relative distribution and seasonal changes of organic phosphorus in hydrosphere compartments.

\section{Approach.}

The approach proposed for identification and analysis of DOP in the hydrosphere is different from previous attempts at DOP characterization in several ways. The first is that the DOP species are to be concentrated and fractionated according to molecular size with ultrafiltration and reverse osmosis membranes. The second difference is the separation of DOP from the concentrated DOC and inorganic salts with non-ionic resins and ion-pairing reagents. Concentrated $D O C$ and inorganic salts can seriously hinder analysis of DOP. A third difference is the use of 31P FT-NMR as an analytical technique for the identification and analysis of DOP. $31 \mathrm{P}$ FT-NMR has the capability to distinguish between DOP species and also provide information regarding the interaction of DOP with DOC. ${ }^{31} \mathrm{P}$ FT-NMR analysis will be extended further by the use of aqueous soluble Lanthanide shift reagents. In addition to 31 P FTNMR, anion exchange HPLC also will be used as a DOP analytical technique. 
SECTION II

SUMMARIES OF PROJECTS COMPLETED

IN FISCAL YEAR 1992 


\section{COMPLEIEDPRONECI}

GRANT NUMBER:

PROJECT TITLE:
14-08-0001-G1305

Solute Segregation During Soil Freezing and Solute and Heat Transport in Permafrost

University of Alaska

J. Gosink and T. Osterkamp

September 1986

October 1991

FINAL DATE RECEIVED:

ABSTRACT:

The primary objectives of this research were to develop a better understanding of salt segregation processes during freezing of saturated soils and of the resulting salt concentration profiles in annually frozen soil and permafrost. Laboratory experiments on the freezing of saline sand columns showed that substantial salt redistribution occurred with downward freezing but not with upward freezing. Convection by salt fingering in the partially frozen region above and below the phase boundary was found to play a major role in the flow and redistribution of salts during freezing. While there was never any evidence for the existence of a salt-enriched layer in the unfrozen region adjacent to the phase boundary, the theory for an effective distribution coefficient was useful in describing salt redistribution during freezing of these saline sands. An analytical solution was developed for the Stefan problem for a freezing saline soil which used an apparent heat capacity formulation in a multiple moving boundary problem. Solutions were obtained for the thermal regime and phase boundary position with temperature-dependent thermal properties. For this problem, a numerical (finite element) model was also developed which was capable of handling a wide range of boundary conditions and initial conditions. The primary problem for developing a model for salt redistribution during soil freezing is that of coupling of heat and salt flow that occurs in the region near the phase boundary (freezing front), through the freezing front, and in the unfrozen region adjacent to the freezing front.

ORDER FROM:

National Technical Information Service

Order Department

Springfield, Virginia 22161

U.S.A. 
PUBLICATIONS:

Baker, G. C. and Osterkamp, T. E., 1989, Salt redistribution during freezing of saline sand columns at constant rates: Water Resources Research, v. 25, n. 8 , p. $1825-1831$.

Baker, G. C. and Osterkamp, T. E., 1988, Implications of salt fingering processes for salt movement in thawed coarse-grained subsea permafrost: Cold Regions Science and Technology, v. 15, p. 45-52.

Osterkamp, T. E., 1987, Freezing and thawing of soils and permafrost containing unfrozen water and brine: Water Resources Research, v. 23, n. 12 , p. $2279-2285$.

Baker, G. C., 1987, Salt redistribution during freezing of saline sand columns with applications to subsea permafrost: Ph.D. thesis, University of Alaska, Fairbanks, Alaska. 
GRANT NUMBER:

PROJECT TITLE:
14-08-0001-G1475

Nucleic Acid and Monoclonal Antibody

Probes for Bacterial Pollutants of

Water Resources Systems

PERFORMING ORGANIZATION: University of Maryland

PRINCIPAL INVESTIGATOR: R. Colwell

START:

August 1987

FINAL DATE RECEIVED:

March 1991

\section{ABSTRACT:}

The problem addressed by this project was the identification of polluted waterresource systems and detection of potentially pathogenic bacteria in groundwater supplies. The objective was to develop novel methods to identify an index bacterium (Escherichia coli) and a bacterial pathogen (Salmonella) in contaminated water. All of the objectives of the project were achieved in that gene probes for Salmonella were developed, modified from a commercially available probe, for application to water systems, and, in addition, monoclonal antibodies (mAbs) were produced and used to detect $E_{\text {c coli and Salmonella }}$ spp. in water samples. The project was successful in preparing monoclonal antibodies specific for $\underline{E}$ coli.

The studies provided unique results in that previously standard bacteriological culture methods used to isolate and identify bacteria easily cultured or in an active state of growth were assumed to be successful in enumerating all viable bacteria in water. It has been established by work done on this project that the majority of bacteria in nutrient-deficient aquatic systems are not readily cultured by traditional methods. The studies further provided methods for detection of viable bacteria that would be undetected by standard methods routinely employed to culture bacteria in water samples.

ORDER FROM:

ORDERNUMBER:
National Technical Information Service

Order Department

Springfield, Virginia 22161

U.S.A.

PB93-118339 
GRANT NUMBER:

PROJECT TITLE:

PERFORMING ORGANIZATION: Cornell University

PRINCIPAL INVESTIGATOR: $\quad$ G. Jirka

START:

FINAL DATE RECEIVED:

\section{$14-08-0001-G 1480$}

Gas Transfer in Streams with Surface Instabilities; White Water Effects and Riffle-Pool Sequences

September 1987

October 1991

\section{ABSTRACT:}

Existing methodologies for the prediction of the air-water surface transfer of gases (for example, dissolved oxygen) in streams and rivers are plagued by large uncertainties related to inadequacies in past experimental work, the lack of a firm theoretical understanding, and the diversity of actual stream conditions. Experimental studies were carried out in the Defrees Hydraulics Laboratory with the objective of examining the transfer mechanism under large-scale, well-controllable laboratory conditions and with detailed and accurate measurement techniques that provide structural insight into the transfer process. Experiments in a grid-stirred tank using a two-dimensional turbulent velocity probe and gas polarographic probe show the fluctuating characteristics of the gas transfer in the near-surface layer (top $1 \mathrm{~mm}$ ). Results are well correlated to a model assuming large-eddy control. Additional grid-stirred tank experiments demonstrate the strong enhancement due to surface instabilities when the water surface is breaking. A large Tilting WindWater Tunnel (TWWT) has been constructed and equipped for transfer studies under diverse flow conditions. A new one-station oxygen transfer measurement technique, which combines long-time gas sampling at one station with a time-oftravel measurement for a dye tracer, gives an accuracy superior over earlier two-station methods. Results from a preliminary test series in the TWWT show a significant and surprising variability of the transfer rate with the turbulent Reynolds number, even though its value is high as typical for field conditions.

ORDER FROM:
National Technical Information Service

Order Department

Springfield, Virginia 22161

U.S.A. 
PUBLICATIONS:

Buzzell, C. A., 1988, Reaeration in a stream with surface instabilities leading to white water: studies on Fall Creek, New York, and laboratory simulations: M. Eng. Design Project, School of Civil and Environmental Engineering, Cornell University.

Jirka, G. H., 1989, Turbulence below the air-water interface and implications on gas transfer: Proc. 23rd Congress, International Association for Hydraulic Research, Ottawa.

Chu, C. -R., 1990, Near-surface turbulent velocity and oxygen concentration measurements in a grid-stirred tank: M.S. Thesis, School of Civil and Environmental Engineering, Cornell University.

Chu, C. -R., and Jirka, G. H., 1990, Turbulent velocity and gas concentration measurements in the surface layers of a grid-stirred experiment: Proc. Second International Symposium on Gas Transfer at Water Surface, Minneapolis. 


\section{COMPLEIEDPRONECI}

GRANT NUMBER:

PROJECT TITLE:
$14-08-0001-G 1485$

Drainage Effects on Salinization, Organic

Matter and Selenium in Wetland Soils

PERFORMING ORGANIZATION: North Dakota State University

PRINCIPAL INVESTIGATOR: J. Richardson

START:

August 1987

FINAL DATE RECEIVED:

August 1991

\section{ABSTRACT:}

The first objective was to compare drained and undrained wetlands in till over shallow shale bedrock, sandy terrains, and in till. In the shale-rich tills, the water tables did not follow the pattern of the till topography in general. The numerous flow reversals and complex interrelated soil patterns result in a natric soil complex that does not seem to change between drained and undrained conditions. Geostatistical analysis demonstrated the importance of recharge and discharge changes during flow reversals; these changes are unaffected by drainage. The late season recharges apparently create the leaching necessary to create natric soils as opposed to saline soils.

In sandy landscapes the natural condition is moderately saline, sodic, and alkaline. After drainage, however, the soils are profoundly impacted and become strongly alkaline, saline, and sodic. Sandy terrains are much more alkaline than other landscapes observed in the state. Drainage of these landscapes results in even higher alkalinity; the land deterioration is such that useful production of crops and forages nearly ceases. Drainage must be extremely restricted here. In their native condition, these landscapes are productive of range grasses and forbs. Drained till landscapes are substantially salinated, and this condition appears to result from drainage.

The second objective was to compare the organic matter changes between drained and natural wetlands. The initial hypothesis that organic matter would decrease on drainage of wetlands because of oxidation was not substantiated. A loss of calcium carbonate on drainage was noted, however. Our current working hypothesis is that calcium carbonate is altered by losses in organic matter but that so little organic matter is lost the bulk is unaffected significantly. 
The third objective was to contrast the amount of selenium in high sulfate zones in wetlands between drained and natural conditions. Theoretically, the Se should be higher in these high sulfate zones than in most other environments. This is the case, but fortunately the levels are still relatively low. On drainage of the wetlands, the elemental and selenite forms of Se should convert to mobile selenate forms. We found evidence that this is the case. Therefore, on drainage of wetlands, selenium mobility should be an important consideration, even though the actual levels observed here are low when compared to established hazard levels.

ORDER FROM:

ORDER NUMBER:
National Technical Information Service Order Department Springfield, Virginia 22161 U.S.A.

PB92-118025 


\section{COMPLEIED PRONECT}

GRANT NUMBER:

PROUECT TITLE:
14-08-0001-G1489

Compatibility of Physically-Based and Linear System Solute Transport Modeling Approaches and Their Conjunctive Application

Volumes I and II

PERFORMING ORGANIZATION: University of Hawaii

PRINCIPAL INVESTIGATOR: $\quad$ C. LIU

START:

August 1987

FINAL DATE RECEIVED:

October 1991

\section{ABSTRACT:}

Volume I

Mathematical models that predict the contamination potential of chemical inputs on the soil surface or in the upper unsaturated soil zone are an increasingly important and useful management tool. Mathematical models can be formulated by following physically based and system approaches. In this study, models based on these approaches were developed to simulate Fenamiphos transport in highly aggregated Hawaiian Oxic soils. Concentration profiles calculated with these models showed rather close similarity to and agreement with measured profiles. Conjunctive use of these models revealed their intrinsic relationship and the consistency between them.

Volume II

Spatial variability of saturated hydraulic conductivity is examined to assess the effect of uncertainty in leaching of pesticides from heterogeneous soils.

Saturated hydraulic conductivity, an important soil parameter that controls the transport of pesticides in soils, is assumed to be composed of a homogeneous mean value and a perturbation caused by the spatial variability of soil properties producing a stochastic process in the mean flow direction. The spatial heterogeneity of porous soils is characterized by the variance and the correlation scale of the saturated hydraulic conductivity in the transport domain. In the first part of the study, numerical experiments are used to investigate the development of scale-dependent macrodispersivity in the 
unsaturated heterogeneous soils. In the second part of the study, the significance of the variance on the spatial and temporal distribution of tracer spreading is demonstrated for Hawaii Oxic soils. The significance of variance regarding the spatial and temporal distribution of tracer concentrations is demonstrated using solute breakthrough curves at various depths in the soil profile. Macrodispersivity values in heterogeneous soils are proportional to the variance at smaller travel distances and converge to the same value at larger travel distances. For greater correlation distances, a faster breakthrough of solutes at various depths was observed.

ORDER FROM:

\author{
National Technical Information Service \\ Order Department \\ Springfield, Virginia 22161 \\ U.S.A.
}

ORDERNUMBER: To be assigned

PUBLICATIONS: $\quad$ PB92-118033 Vol I

PB92-118041 Vol II

Liu, C. C. K., Loague, K. M., and Feng, J. -S., 1991, Fluid flow and solute transport in unsaturated heterogeneous soils: numerical experiments: Journal of Contaminant Hydrology, 7, p. 261-283.

Liu, C. C. K., Feng, J. -S., and Chen, W., 1991, System modeling approach for solute transport through upper soils: Water Science and Technology, 24(6), p. 67-72.

Liu, C. C. K., 1991, Stochastic analysis of contaminant transport in heterogeneous soils using numerically synthesized soil columns: Proceedings of the International Conference on Computer Applications in Water Resources, v. II, Yamkang University, Taiwan, p. 1091-1098.

Chen, W. and Liu, C. C. K., 1991, Modeling chemical transport in soils by the method of system parameterization: Proceedings of the International Conference on Computer Applications in Water Resources, V. II, Yamkang University, Taiwan, p. 821-828.

Liu, C. C. K., 1989, Solute transport modeling in heterogeneous soils: conjunctive application of physically based and system approaches: Journal of Contaminant Hydrology, 3, p. 97-111. 


\section{COMPLEIEDPRQNECT}

GRANT NUMBER:

PROJECT TITLE:

PERFORMING ORGANIZATION:

PRINCIPAL INVESTIGATORS:

START:

FINAL DATE RECEIVED:
14-08-0001-G1494

Microbial Dehalogenation of a Hexachlorinated PCB at Low Redox

Potential

University of Pittsburgh

R. Neufeld and S. Pedersen

September 1987

September 1991

\section{ABSTRACT:}

In three studies using a single polychlorinated biphenyl (PCB) congener, $2,2^{\prime}, 4,4^{\prime}, 5,5^{\prime}$ - hexachlorobiphenyl (HCB), degradation was observed at soil concentrations between 1000 and $1500 \mathrm{mg} \mathrm{HCB} / \mathrm{KG}$ soil, but not in a fourth study conducted at $100 \mathrm{mg} \mathrm{HCB} / \mathrm{KG}$ soil. Degradation did not occur in controls poisoned by $0.1 \%$ mercuric chloride. Degradation was enhanced by the addition of a nutrient solution at approximate ratios of 100TOC:2N:1P. The degradation was observed in both soil and sand matrices. A final study with Aroclor 1260 incubated for 44 days showed only degradation of the HCB.

A study of different reducing agents revealed mixed effects on the degradation process; addition of equal parts of 1-cystine hydrochloride and sodium dithionite appeared to enhance degradation, while the use of 2 parts of sodium dithionite alone had little effect; degradation was observed when no reducing agents were added, or when only 1-cystine hydrochloride was added. Measurements of the redox potential of these cultures showed that each combination of agents influenced the redox potential of the cultures differently. Inoculating the HCB contaminated soil with an inoculum of chlorobenzoate dechlorinating bacteria from the University of Michigan resulted in degradation of the HCB; the rate of degradation was similar to degradation rates observed in other studies within the research program.

\section{ORDER FROM:}

National Technical Information Service Order Department

Springfield, Virginia 22161

U.S.A. 
ORDER NUMBER:

PB92-151687 


\section{COMPLEIEDPROJECI}

GRANT NUMBER:

PROJECT TITLE:

\section{4-08-0001-G1504}

A Novel Non-Lethal Field Bioassay for Predicting Stream Water Quality Impaired by Heavy Metals and Low $\mathrm{pH}$

PERFORMING ORGANIZATION: Pennsylvania State University

PRINCIPAL INVESTIGATOR: W. Dunson

START:

August 1987

FINAL DATE RECEIVED:

September 1992

\section{ABSTRACT:}

The use of changes in whole body ion levels of stream organisms as a physiological bioindicator of water pollution by metals and acidity in coal mine effluents was tested. We compared: (1) lethality tests to body sodium loss after exposure of fathead minnows to simulated and field-collected mine water; (2) developed a predictive model of body ion loss in brook trout from water variables; (3) tested for $\mathrm{H}^{+}$/metals interactions in reconstituted mine water (RMW); and (4) determined if stonefly larvae exposed to RMW respond similarly to fish.

We found that: (1) changes in sodium levels of minnow matched lethality tests; (2) a model predicting sodium flux from trout exposed in mine-polluted streams was highly significant; (3) sodium loss from brook trout exposed in RMW at severe pollution levels was primarily due to acidity; at moderate levels $\mathrm{Ni}, \mathrm{Mn}$, and $\mathrm{Zn}$ blocked the effect caused by acidity alone; and (4) the response of stonefly larvae to mine pollution was similar to that of fish, but with decreased sensitivity.

We conclude that whole body net sodium flux is a sensitive, reproducible bioindicator of toxic levels of acid and metals; and can be used to predict the combined toxicity of these variables in coal mine polluted streams.

ORDER FROM:

National Technical Information Service

Order Department

Springfield, Virginia 22161

U.S.A.

ORDER NUMBER:

PB93-123958 


\section{PUBLICATIONS:}

Gonzalez, R. J., Grippo, R., S. and Dunson, W. A., 1990, The disruption of sodium balance in brook charr, salvelinus fontinalis (Mitchill), by manganese and iron: Journal of Fish Biology, 37, p. 765-774. 


\section{COMPLEIEDPROUECT}

GRANT NUMBER:

PROJECT TITLE:
14-08-0001-G1623

A Novel Closed Loop Air Stripping Process for Volatile Organic Compounds (VOC) Removal from Contaminated Water

PERFORMING ORGANIZATION: University of Minnesota

PRINCIPAL INVESTIGATORS: M. Bhowmick, T. Sontag, and

M. Semmens

START:

September 1987

FINAL DATE RECEIVED:

October 1990

\section{ABSTRACT:}

This report presents an approach for the treatment of contaminated ground water. VOCs are stripped from the water, using hollow fiber membranes or using conventional air stripping technology, and then the VOCs are oxidized in the gas phase using ultraviolet (UV) oxidation or a combination of photooxidation and photo-catalysis with Titanium Dioxide (TiO2). The work on the photo-oxidation of VOCs is applicable to both water and soil treatment techniques, such as air stripping and in situ vacuum extraction.

The report is divided into five major segments:

(1) the investigation of VOCs oxidation in the gas phase using UV light with an examination of the mechanisms;

(2) the modeling and testing of the proposed treatment technique, in which the photo reactor is coupled with hollow fiber membrane stripping system;

(3) the adsorption of VOCs to $\mathrm{TiO} 2$, a photoactive catalyst proposed for use in the photo reactor;

(4) a comparison of the photo-oxidation of VOCs in the presence and in the absence of $\mathrm{TiO} 2$; and

(5) the modeling and experimental verification of the kinetics of the photo catalytic reactor system. 
Each segment includes relevant sections on the experimental methods employed, the results from the tests conducted, the development of models, and the conclusions that were drawn from the work.

ORDER FROM:

National Technical Information Service

Order Department

Springfield, Virginia 22161

U.S.A.

ORDER NUMBER:

PB92-218247 


\section{COMPLEIEDPROJECT}

GRANT NUMBER:

PROJECT TITLE:

\section{4-08-0001-G1625}

The Effects of Humic Substances on the Interactions of Metal lons with Organisms and Liposomes

PERFORMING ORGANIZATION: University of California, Davis

PRINCIPAL INVESTIGATOR: J. Swinehart

START:

September 1987

FINAL DATE RECEIVED:

April 1992

\section{ABSTRACT:}

The project investigated: (1) the level at which humic acid (HA) affects the uptake of $\mathrm{Pb}(I I), \mathrm{Cd}(I I), \mathrm{Zn}(I I), \mathrm{Hg}(I I)$, and $\mathrm{Cu}(\mathrm{II})$ by Chinook salmon, steelhead trout eggs and excised molluscan, and unio gills; and (2) the interactions of the above metal ions with liposomes. The research found that: (1a) the uptake of $\mathrm{Hg}$ (II) by eggs is most strongly affected by HA; (1b) metal ions compete for sites on eggs, and losses of $\mathrm{Ca}(\mathrm{II})$ and $\mathrm{Mg}(\mathrm{II})$ from eggs are induced by metal ions at $10^{-5} \mathrm{M} ;(1 \mathrm{c})$ metal ions have little effect on amino acids losses from eggs; (1d) $\mathrm{Hg}$ (II) remains in egg chorions, while $\mathrm{Cd}(\mathrm{II})$ and $\mathrm{Zn}$ (II) migrate to the yoke; (1e) $\mathrm{Hg}(\mathrm{II})$, but not the other metals, enhances the loss of amino acids from gills; and (1f) $\mathrm{HA}$ increases the uptake of $\mathrm{Hg}(\mathrm{II})$ by gills, but does not affect the uptake of other metal ions; and (2a) metal ions bind to different sites on phospholipids; (2b) metal ions exhibit different binding patterns towards combinations of phospholipids; and (2c) only at $10^{-4} \mathrm{M}$ do metal ions enhance the loss of dyes from liposomes. The methods employed in problem (1) were measurement of the uptake of metal ions at varying concentrations of $\mathrm{HA}$ using radio tracers, and measurement of amino acid and biological metals using fluorescence and atomic absorption methods. The methods used in problem (2) were use of radio tracers to measure association of metal ions to lipid vesicles and measurement of metal ion-induced loss of dyes from liposomes. The results apply to the interactions of pollutant heavy metal ions with freshwater organisms such as fish eggs and molluscs, and address the question of the role phospholipids play in the processes observed for the interactions of metal ions with the organisms studied. 
ORDER FROM:

National Technical Information Service

Order Department

Springfield, Virginia 22161

U.S.A.

ORDER NUMBER:

PB92-220128 
GRANT NUMBER:

PROJECT TITLE:

PERFORMING ORGANIZATION: University of California

PRINCIPAL INVESTIGATOR:

START:

FINAL DATE RECEIVED:
14-08-0001-G1626

A Study of Growth, Resource Allocation, and Nutrient Requirements of

Myriophyllum Aquaticum

M. Rejmanek

September 1988

March 1991

\section{ABSTRACT:}

The main purpose of the study was to develop the fundamental biological understanding of $\underline{M}$. aquaticum growth, nutrient requirements and allocation patterns necessary for effective, economical, and environmentally sound management strategies.

The criteria for assessment of $N$ and $P$ deficiency in $M$. aquaticum, established in the laboratory, indicated that nutrient limitation was present in some of the field populations studied. Intensive sampling of the Park's Lake population indicated that both $\mathrm{N}$ and $\mathrm{P}$ were below the critical concentration over much of the growing season. The ratio of meristem-leaf $N: P$ indicated that $N$ was more limiting than $P$ early in the growing season but that $P$ became more limiting later in the growing season. Differing availability's of $N$ and $P$ during the growing season were evident in rhizome $N$ and $P$ concentrations. The switch from primarily $\mathrm{N}$ to primarily $\mathrm{P}$ limitation in Park's Lake during August coincided with a decline in productivity, suggesting that the major limitation to growth of $\mathrm{M}$. aquaticum in Park's Lake was the rate of $P$ supply.

There was a gradient in productivity with depth. Productivity in the shallow, near-shore area was greater than in the deep, off-shore area. The productivity depth-gradient may be related to access to sediment $N$ and $P$. Adventitious roots that form on the rhizomes in the water column are usually no greater than $30 \mathrm{~cm}$ in length. Therefore, plants in water deeper than 30 to $50 \mathrm{~cm}$ do not have access to sediment nutrients via the adventitious roots, and must rely upon nutrients in the watercolumn. 
M. aquaticum growth in San Joaquin County drainage ditches was not limited by $\mathrm{N}$ or $\mathrm{P}$. The drainage ditches were typically nutrient-rich environments, with high nutrient loading from agricultural runoff and irrigation return flows. Although stem densities in these habitats are not significantly higher than those observed in lentic systems, emergent stem lengths were usually greater. Stem elongation is a typical response to competition for light.

ORDER FROM:

National Technical Information Service

Order Department

Springfield, Virginia 22161

U.S.A.

ORDERNUMBER:

PB93-123966

PUBLICATIONS:

Systma, M. and Anderson, L., 1989, Parrotfeather: impact and management:

Proceedings, 41st Annual California Weed Conference, Ontario, Canada, 16-18, p. 137-146. 


\section{COMPLEIED PROJECT}

GRANT NUMBER:

PROJECT TITLE:

\section{4-08-0001-G1629}

Water Quality Enhancement via Integrative Procedures for Urban Non-point Source Water Pollution and Flood Control

PERFORMING ORGANIZATION: Georgia Institute of Technology

PRINCIPAL INVESTIGATOR:

A. Esogbue

START:

September 1988

FINAL DATE RECEIVED:

December 1991

\section{ABSTRACT:}

Non-point source water pollution and flooding create problems that have serious impacts on both quantity and quality problems in urban water resources management. Despite various attempts to deal with them, serious difficulties continue to be encountered by water resources managers and planners. In this effort, we proposed a novel approach to the flood control problem as well as the non-point source water pollution control problem by recourse to the tools of fuzzy sets and possibility theory, mathematical programming and utility theory. This approach provides the researcher with a more close to reality representation of complex or ill defined phenomena as employed by planners. Since these problems integrate engineering, economic, environmental, social and management aspects and therefore deal with entities and relations that are often not precisely known or difficult to quantify, a fuzzy approach appeared to be more natural and appropriate than classical methods.

The report is organized as follows: In Chapter One, we motivate the problem, review previous studies, and state the project objectives and our project design. In Chapter Two, we present our fuzzy mathematical model of the problem for both the flood control and non-point source pollution control problems. The problem is modeled via a fuzzy hierarchical multi-stage resource allocation framework. Version One treated in this chapter employs a modification of a branch and bound algorithm first proposed by Kacpryzk, while the second version given in Chapter Three requires data inputs in their simplest and most natural occurring setting. A three-phase optimization procedure is proposed, with the first two dealing with regional and national allocation models and a third playing the role of coordination. In Chapter Four, we exercise our two versions of the algorithm on a flood control problem, while 
its equivalent water pollution model is discussed in Chapter Five. Data issues critical to the successful implementation of the models in a real world setting are treated in Chapter Six. The Appendix contains the flow charts for the algorithms, the attendant computer programs, and other related project issues.

ORDER FROM:

National Technical Information Service Order Department

Springfield, Virginia 22161

U.S.A.

ORDER NUMBER:

PB92-220144 


\section{COMPLETEDPRQUECT}

GRANT NUMBER:

PROJECT TITLE:

PERFORMING ORGANIZATION: New Mexico State University

PRINCIPAL INVESTIGATOR:

START:

FINAL DATE RECEIVED:
$14-08-0001-G 1632$

Ground-water Quality in Pumping Wells

Located Near Surface Water Bodies

\section{ABSTRACT:}

Well-water quality depends on the relative amounts of water drawn from different hydrologic units (aquifers, streams, and so forth), and the particular capture zones within those units. A contaminant spilled within an aquifer capture zone will eventually enter the well. A spill outside the capture zone may eventually discharge elsewhere, perhaps to a nearby stream. If under normal circumstances the stream is gaining, pumping can locally reverse gradients, causing it to become losing. Stream water can then enter the well by induced infiltration. For wells located near surface water bodies, a variety of two- and three-dimensional analytical and numerical models of induced infiltration and capture zones are presented. Induced infiltration does not seem to be very sensitive to the ambient flow sources, whether it is local vertical recharge or lateral inflow. Two types of capture zones are defined: ultimate capture zone that include the portion of the aquifer that will eventually discharge to the well, and time-dependent capture zones that include only that portion of the aquifer that discharges to the well within a prescribed time. Capture zones are strongly influenced by the source and direction of ambient aquifer flow, nearby aquifer boundaries, and three-dimensional flow caused by partial penetration of the well or the stream. Capture zone models involve uncertain parameters that lead to 'fuzzy' capture zone boundaries. These boundaries are illustrated for a simple model. Hydrodynamic and macro dispersion are other sources of uncertainty. They allow a particle to wander across the capture zone boundary. Thus, a source of contamination outside the capture zone has a finite probability of being incorporated into the well water. Another interpretation of these probabilities, at least for long-term continuous sources of contamination, is that they define the proportion of the contaminant that will eventually find its way to the well. 
ORDER FROM:

National Technical Information Service

Order Department

Springfield, Virginia 22161

U.S.A.

ORDER NUMBER:

PB92-127356

PUBLICATIONS:

Schafer-Perini, A. L. and Wilson, J. L., 1991, Efficient and accurate front tracking for two-dimensional groundwater flow models: Water Resources Research, v. 27 (7), p. 1471-1485. 


\section{COMPLEIEDPROJECT}

GRANT NUMBER:

PROJECT TITLE:

PERFORMING ORGANIZATION:

PRINCIPAL INVESTIGATOR:

START:

FINAL DATE RECEIVED:
14-08-0001-G1636

Microbial Transformations in

Alkali Lake, Oregon

Oregon Graduate Institute of Science

and Technology

D. Boone

August 1988

October 1991

\section{ABSTRACT:}

We examined the terminal metabolic processes in subsurface sediments near West Alkali Lake, Oregon, by performing microbial counts of methanogenic bacteria and isolating the predominant methanogenic culture. This methanogen was characterized and found to be physiologically and phylogenetically different from other described strains, so it represents a previously undescribed species of bacterium, which we named "Methanohalophilus oregonensis." In contrast to published descriptions of many other methanogens that have been isolated from hypersaline environments, this one is halotolerant rather than halophilic. Another important characteristic of this organism is that it is capable of catabolizing dimethylsulfide or methanethiol. This ability is important because these methylated sulfur compounds are major conduits by which sulfur moves between the atmosphere and terrestrial and aquatic ecosystems. We collaborated with Ron Oremland (U.S. Geological Survey, Menlo Park) who determined that "M. oregonensis" does not demethylate dimethylmercury. We also found that it can grow in defined medium, with the only organic addition to the medium being its catabolic substrate and the vitamin thiamine. We have isolated from an oil well in the Gulf of Mexico another methanogen (strain HI350) which degrades dimethylsulfide. Phylogenetic comparisons to known methanogens showed that this strain is closely related to another methanogen, "Methanolobus siciliae" T4/M, that was named but not described. During our characterization of strain HI350, we also characterized the type strain of "M. siciliae."

ORDER FROM:
National Technical Information Service Order Department Springfield, Virginia 22161 U.S.A. 


\section{PUBLICATIONS:}

Liu, Y., Boone, D. R., and Choy, C., 1989, Methanohalophilus oregonense sp. nov., a methylotrophic methanogen from an alkaline, saline aquifer: International Journal of Systematic Bacteriology, v. 40, p. 111-116.

Robertson, D. E., Noll, D., Robert, M. F., Menaia, J. A. G. F., and Boone, D. R., 1990, Detection of the osmoregulator betaine in methanogens: Applied Environmental Microbiology, v. 56, p. 563-565.

Robertson, D. E., Roberts, M. F., Belay, N., Stetter, K. O., and Boone, D. R., 1990, Occurrence of B-glutamate, a novel osmolyte in marine

methanogenic bacteria: Applied Environmental Microbiology, v. 56 , p. 15041508. 


\section{COMPLEIEDPRONECT}

GRANT NUMBER:

PROJECT TITLE:

PERFORMING ORGANIZATION:

PRINCIPAL INVESTIGATOR:

START:

FINAL DATE RECEIVED:
$14-08-0001-G 1637$

Model for Regional Solute Transport

Suited for Calibration and Management

\section{ABSTRACT:}

A Purely Advective Approach is followed to develop a practical model for regional solute transport. First, it is shown that it is not theoretically sound to use the traditional advective-dispersive governing equation. The stochastic approach demonstrates that a dispersion coefficient can be defined only under extremely rare and unpractical conditions. Thus, a detailed velocity field must be determined. To define such a velocity field, the hydraulic conductivity field itself must be well defined. Calibration techniques to determine such fields were investigated which can, at least in principle, obtain it continuously in space. A model was developed which is purely advective. The model was compared to the U.S. Geological Survey model MOC. The results indicate that the model works as well as MOC, but not better. This was a disappointment and is due to a procedure (Kriging) which introduced numerical dispersion. A new approach to avoid numerical dispersion has been developed but has not been tested yet.

ORDER FROM:

National Technical Information Service Order Department Springfield, Virginia 22161 U.S.A.

ORDERNUMBER:

PB92-161371

PUBLICATIONS:

Morel-Seytoux, H. J. and Nuchabe, M., accepted for publication, An effective scale-dependent dispersivity deduced from a purely convective flow field: Hydrological Sciences Journal. 


\section{COMPLEIEDPRONECT}

GRANT NUMBER:

14-08-0001-G1639

PROJECT TITLE:

Institutional Response to a Changing

Water Policy Environment

PERFORMING ORGANIZATION: University of Arizona

PRINCIPAL INVESTIGATOR: $\quad$ F. Gregg

START:

September 1988

FINAL DATE RECEIVED:

December 1991

\section{ABSTRACT:}

Demand patterns for the nation's water resources have changed during the past several decades at a rate that has exceeded the adaptive capacities of water policies and institutions. This study developed an integrated analytical framework, based in part on the work of Elinor Ostrom, to study the process of institutional change in water management institutions. This framework was then used to analyze institutional change in nine settings, including ground-water management in Arizona, interstate water allocation in the Delaware basin, and integrated land and water management in Florida. This method of analysis provides a means of integrating different types of water resources management problems, the institutional changes needed to address these problems, and varying policy approaches.

ORDER FROM:

ORDER NUMBER:
National Technical Information Service Order Department

Springfield, Virginia 22161

U.S.A.

PB92-161405 


\section{COMPLETED PROJECT}

GRANT NUMBER:

PROJECT TITLE:

PERFORMING ORGANIZATION:

PRINCIPAL INVESTIGATORS:

START:

FINAL DATE RECEIVED:
14-08-0001-G1641

Increased Water-Use Efficiency in

Alfalfa by Selection for Two Key

Heritable Physiological Traits

New Mexico State University

V. Gutschick and C. Currier

September 1988

July 1992

\section{ABSTRACT:}

Physiological breeding to improve crop water-use efficiency is one of several complementary approaches to problems of agricultural water use, such as competition with other end-users and soil salinization, and to problems of declining or erratic water supplies for agriculture itself. In previous work, we developed a physiologically based model, which predicted that breeding for two specific traits might confer 10 percent increases in water-use efficiency (WUE) on alfalfa in large-field growth over the whole season, while only modestly depressing yield. We report here more detailed tests of the hypothesis about WUE gains and their cost in reduced yield. These tests, in both controlled and field environments, also provided evidence that two traits, $\mathrm{C}_{1}\left(\mathrm{CO}_{2}\right.$ concentration maintained in the leaf interior), and SLM (specific leaf mass or mass per area), are usable for breeding because they are (1) heritable, (2) stable in expression between repeated growth cycles and between modestly different growth environments, and (3) measurable for selection by accurate, cost-effective methods. We recommend that (1) primary attention should be paid to water management to conserve water in agriculture, in view of the rather modest and stringent limits on improving WUE by plant breeding, which is apparent in both comprehensive models and experiments here and elsewhere; (2) while these limits on WUE should be accounted in allocating research efforts, a cultivar with low $\mathrm{C}_{1}$ and increased SLM should be developed for field trials; such breeding will be needed for future marginal gains in water conservation; other possibilities for breeding crops of superior WUE, especially selecting lower chlorophyll content of leaves will be more difficult but ultimately useful; $(3)$ in breeding selection, $\mathrm{C}_{1}$ should be measured by mass-spectrometric 
determination of carbon-isotope discrimination at national facilities; (4) the design and interpretation of WUE in field trials should take careful account of effects of interplant competition and the micrometeorological conditions should be fully defined, particularly the canopy boundary-layer resistance; and (5) future breeding for WUE must account for some demonstrated trade-offs with crop drought tolerance and yield.

ORDER FROM:

National Technical Information Service

Order Department

Springfield, Virginia 22161

U.S.A.

ORDER NUMBER:

PB92-218254 


\section{COMPLETED PRONECT}

GRANT NUMBER:

PROJECT TITLE:
14-08-0001-G1644

Economic Impacts of Alternative Water Allocation Instructions in the Colorado River Basin

PERFORMING ORGANIZATION: Colorado State University

PRINCIPAL INVESTIGATOR: $\quad$ R. A. Young

START:

September 1988

FINAL DATE RECEIVED: $\quad$ December 1991

\section{ABSTRACT:}

Colorado River water is the dominant water supply for much of the southwestern United States, satisfying agricultural, municipal, and industrial needs. Basin water is now fully utilized, and increasing off-stream demands, particularly in rapidly growing Arizona and southern California, will cause increasing pressure on the basin water. Non-consumptive uses of Colorado River water (hydropower, salinity control) physically interact with consumptive uses and are also of increasing economic significance. Water transfers would require foregoing some existing uses and would be possible only with significant institutional changes in the set of compacts, state laws, and court decisions which together control allocation of Colorado River water. The objective of this work was to evaluate policies for increasing beneficial use of basin water resources. This was achieved by estimating consumptive and nonconsumptive use benefits using a nonlinear economic optimization model employing a national perspective. Water demand sectors are linked with river flows to find allocations maximizing net economic surplus under alternative institutions. All major use sectors are integrated in an economic-hydrologic optimization model. Solutions are found under priorities governing present allocation, and under increased intra- and interstate trade between existing consumptive and non-consumptive users. Model solutions are presented using estimates of present and future economic demands under two levels of basin water flow, one representing the long-term mean, while the second simulates serious drought. Within-state water transfers are found to be particularly effective for increasing net consumptive use benefits during droughts. 
ORDER FROM:

ORDER NUMBER:
National Technical Information Service Order Department

Springfield, Virginia 22161

U.S.A.

PB92-161389 


\section{COMPLEIEDPRQNECT}

GRANT NUMBER:

PROJECT TITLE:
14-08-0001-G1645

A Field Study for Model Validation

of Multi-Dimensional Flow and

Transport in the Vadose Zone

PERFORMING ORGANIZATION: New Mexico State University

PRINCIPAL INVESTIGATOR: $\quad$ D. B. Stephens

START:

September 1988

FINAL DATE RECEIVED: January 1992

\section{ABSTRACT:}

A comprehensive field experiment was conducted to determine geologic controls on water flow and solute transport in a heterogeneous vadose zone. The experiment was conducted on a $10-\mathrm{m}$ by $10-\mathrm{m}$ plot underlain by heterogeneous beds of clays, sands, gravels, and cobbles of alluvial and fluvial origin. The plot and surrounding area was instrumented with 21 neutron probe access tubes, 168 tensiometers, and 62 solution samplers. Steady water application was provided by a drip irrigation system. Measurements of subsurface wetting and drainage were conducted by using a multitracer transport experiment, in situ and laboratory determinations of hydraulic parameters, and destructive geologic characterization. The results of all determinations reflected the extreme short-scale geologic variability of the subsurface material. Attempts to model the flow and transport behavior was only partially successful.

The project provided a detailed characterization of a vadose zone typical of those found throughout the western United States. The extensive data base developed under controlled conditions may be useful for future modeling activities.

ORDER FROM:

ORDERNUMBER:
National Technical Information Service

Order Department

Springfield, Virginia 22161

U.S.A.

PB92-161363 


\section{COMPLEIED PROAECT}

GRANT NUMBER:

PROJECT TTLE:
14-08-0001-G1648

Development of Biologically Relevant Methods for the Determination of Bioavailable Aluminum in Surface Waters

PERFORMING ORGANIZATION: University of Wyoming

PRINCIPAL INVESTIGATOR: $\quad H$. Bergman

START:

September 1988

FINAL DATE RECEIVED:

October 1992

\section{ABSTRACT:}

Surface water acidification is often accompanied by elevated aluminum concentrations that may be toxic to fish. Measured concentrations of total aluminum often do not accurately reflect the observed toxicity. None of the available methods for measuring the presumed toxic fraction, inorganic monomeric aluminum, are effective. The objective of this project was to develop a new method for measuring the toxic, or bioavailable, fraction of aluminum. We determined the apparent binding affinity of fish gills for aluminum by exposing brook trout and rainbow trout to aluminum in the presence of organic acids of known aluminum binding affinity. We then attempted to modify the performance characteristics of five cation exchange resins to match the apparent binding affinity of fish gills for aluminum. However, none of the resins achieved the desired separation of toxic and nontoxic fractions. To achieve this separation, it may be necessary to first synthesize a new class of lowaffinity cation exchange resins. Further pursuit of this competitive bioassay/biologically calibrated cation exchange chromatography approach will likely result in a fractionation method for aluminum and other toxic, surfaceactive metals such as copper and zinc.

ORDER FROM:

ORDERNUMBER:
National Technical Information Service Order Department Springfield, Virginia 22161 U.S.A.

PB93-123636 


\section{PUBLICATIONS:}

Fernandez, J. D., Kline, E. R., and Bergman, H. L., 1990, A method for determining bioavailable aluminum in acidic surface waters: Society of Environmental Toxicology and Chemistry Annual Meetings, Arlington, Virginia, November 1990. (Abstract in Proceedings).

Bergman, H. L. and Fernandez, J. D., 1990, Development of a proposed new analytical method based on metal complexation and bioavailability: EPA Workshop on Recommendations for Revision of National Water Quality Criteria Guidelines, Washington, D.C., December 1990.

Kline, E. R., 1992, The effects of organic complexation on aluminum toxicity in rainbow trout (Oncorhynchus mykiss): M.S. Thesis, University of Wyoming, Laramie, $68 \mathrm{p}$. 


\section{COMPLEIED PROJECT}

GRANT NUMBER:

PROJECT TITLE:

PRINCIPAL INVESTIGATOR:

START:

FINAL DATE RECEIVED:
14-08-0001-G1650

Recombinant Organisms in the Drinking Water System: Survival, Plasmid Transfer, and the Role of Surfaces

PERFORMING ORGANIZATION: University of Delaware

D. Herson

September 1988

October 1991

\section{ABSTRACT:}

We used triparental matings to demonstrate transfer (mobilization) of the nonconjugative genetically engineered plasmid pHSV106 from Escherichia coli HB101 (pHSV106) to an environmental isolate of Enterobacter cloacae in sterile drinking water. pHSV106 contains the ampicillin resistance gene. Mobilization was mediated by the R-plasmid R100-1 of E. coli ED2149 (R100-1). Matings in drinking water yielded increasing numbers of recombinants between $15^{\circ}$ and $35^{\circ} \mathrm{C}$. High concentrations of all three parental organisms were required for successful formation of recombinants in drinking water.

Parental organisms and recombinants remained viable during a week of incubation in drinking water in the absence of indigenous organisms and declined in their presence. Using oligonucleotide probes for the thymidine kinanse and ampicillin resistance genes, we determined that one of the recombinants resulting from mobilization contained rearranged forms of pHSV106. When this recombinant was incubated for nine days in filter-sterilized drinking water its population size remained unchanged and the recombinant maintained its rearranged plasmids. After the initial rearrangement, the fate of the plasmid depended on the conditions under which the cells were cultured.

ORDER FROM:
National Technical Information Service

Order Department

Springfield, Virginia 22161

U.S.A. 
PUBLICATIONS:

Sandt, C. H. and Herson, D. S., 1989, Plasmid mobilization from a genetically engineered microorganism to an environmentally isolated strain of Enterobacter cloacae: Paper N-53, American Society for Microbiology Annual Meeting. New Orleans, Louisiana.

Sandt, C. H. and Herson, D. S., 1990, Plasmid rearrangements associated with mobilization of the genetically engineered plasmid pHSV106 from Escherichia coli HB101(pHSV106) to an environmental isolate of Enterobacter cloacae in drinking water: Paper Q-159, American Society for Microbiology Annual Meeting. Anaheim, California.

Sandt, C. H. and Herson, D. S., 1991, Mobilization of the genetically engineered plasmid pHSV106 from Escherichia coli HB101(pHSV106) to Enterobacter cloacae in drinking water: Applied and Environmental Microbiology, v. 57, p. 194-200. 
GRANT NUMBER:

PROJECT TITLE:

\section{4-08-0001-G1651}

Water and Chemical Movement Through the Biologically Active Surface Layer of No-Till Soils

PERFORMING ORGANIZATION: Ohio State University Research

Foundation

PRINCIPAL INVESTIGATORS: $\quad$ W. Dick and E. McCoy

START:

September 1988

FINAL DATE RECEIVED:

May 1992

\section{ABSTRACT:}

Macropores created by earthworms have been implicated in the rapid movement of water and chemicals through the biologically active surface layer of no-till soils. These macropores are especially evident when no-tillage is continually practiced due to lack of mechanical disruption of the soil. We sampled undisturbed soil blocks $\left(30 \mathrm{~cm}^{3}\right)$ from long-term no-tillage fields and conventional tillage fields in Ohio. Strontium bromide and atrazine were applied as chemical tracers and simulated rain was applied in the laboratory. Results indicate that continuous no-tillage creates a greater number of macropores than is observed for conventional tilled soil. However, similar models can be used to describe macropore flow for both tillage systems. In no-tillage soil, surface residues direct water to macropores and this water may contain enhanced concentrations of chemicals if the chemicals are still located on the residue surface at the time of a rainfall event. If a small rainfall event occurs and washes off the chemical from the residue into the soil matrix, then the macropores act as conduits of water that is relatively unaffected by the chemicals in the soil matrix. On the basis of our laboratory results, we do not see any reason to recommend to farmers that they periodically till their fields to prevent macropore formation and enhanced movement of chemicals through the soil profile.

ORDER FROM:

ORDER NUMBER:
National Technical Information Service

Order Department

Springfield, Virginia 22161

U.S.A.

PB92-205111 


\section{PUBLICATIONS:}

Shipitalo, M. J., Edwards, W. M., Dick, W. A., and Owens, L. B., 1990, Initial storm effects on macropore transport of surface-applied chemicals in no-till soil: Soil Science Society of America Journal, v. 54, p. 1530-1536.

Edwards, W. M., Shipitalo, M. J., Dick, W. A., and Owens, L. B., 1991, Rainfall intensity affects transport of water and chemicals in no-till soil:

Soil Science Society of America Journal, v. 56, p. 52-58. 
GRANT NUMBER:

PROJECT TITLE:

\section{4-08-0001-G1652}

Variable Density Ground-Water Flow Near a Closed-Basin Saline Lake:

A Case Study at Mono Lake, California

PERFORMING ORGANIZATION: University of California

PRINCIPAL INVESTIGATORS: S. Dreiss and D. Rogers

START:

September 1988

FINAL DATE RECEIVED: $\quad$ September 1991

\section{ABSTRACT:}

Rates and directions of ground-water circulation in the Mono Basin are strongly influenced by: (1) the distribution of recharge from surrounding mountain ranges; (2) density differences between saline waters near the terminal lakes and relatively dilute recharge waters; and (3) structural features and lithologic heterogeneities. We used observations at several transects around Mono Lake and variable density ground-water flow models to examine ground-water circulation patterns near the lake shoreline. We demonstrate that the presence of relatively dense, saline water beneath the lake may influence circulation in several ways. A convection cell may develop beneath the lake driven by sinking, dense, lake waters and mixing of these waters with relatively fresh recharge waters. The position of the interface between relatively fresh and saline waters is a function of recharge rates and lake salinity. Fresh water flow, impeded by the interface with denser water, will circulate upward forming localized springs and seeps along the lakeshore.

Our simulations suggest that recharge rates from the Sierra Nevada are sufficient to push the interface beneath the west side of the lake. This is consistent with observations of tufa formations and sizable springs issuing from the lake bottom on this side of the lake. In contrast, on the northeast side where recharge rates are low, the interface may extend landward of the shoreline and contribute solutes to the salt crust that has formed on the exposed lakebed. 
ORDER FROM:

National Technical Information Service Order Department

Springfield, Virginia 22161

U.S.A.

ORDER NUMBER:

PB91-242867 


\section{COMPLEIEDPRONECT}

GRANT NUMBER:

PROJECT TITLE:
14-08-0001-G1657

The Effects of Wetting on Transport of Organics in Ground Water

PERFORMING ORGANIZATION: New Mexico State University

PRINCIPAL INVESTIGATORS: $\quad$ R. Bowman and J. Wilson

START:

September 1988

FINAL DATE RECEIVED:

August 1992

\section{ABSTRACT:}

We investigated the effects of altered surface chemistries on fluid saturations, flow characteristics, and sorption properties in model porous media. Two distinct lines of inquiry were pursued. The first was to evaluate effects of surface chemistry on wettability and pressure/saturation relationships of chemically modified silica. The second line of inquiry was to modify the surface chemistry of natural zeolite and determine the effects of such modification on sorption of organic chemicals.

We found that we could create silica surfaces of different wettabilities that were stable for hundreds of hours in aqueous systems. We used these modified silicas to determine pressure/saturation relationships for water/oil systems and related the observations to measurements of wettability. We showed that we could use quaternary ammonium cations to predictably alter the sorptive properties of natural zeolites.

Our model experiments showed that basic information on surface characteristics can be used to successfully predict changes in fluid dynamics and sorption properties of porous media.

ORDER FROM:

ORDERNUMBER:
National Technical Information Service Order Department Springfield, Virginia 22161 U.S.A.

PB93-123941 


\section{COMPLEIED PROSECT}

GRANT NUMBER:

PROJECT TITLE:
$14-08-0001-G 1723$

Evaluation of Mechanisms of Microbial

Alteration and Humification of

Polynuclear Aromatic Hydrocarbons

(PAHS) for Water Quality Management

PERFORMING ORGANIZATION: Utah State University

PRINCIPAL INVESTIGATOR: $\quad$ R. Sims

START:

September 1989

FINAL DATE RECEIVED: $\quad$ September 1992

\section{ABSTRACT:}

There is a current lack of knowledge concerning the behavior of PAHs in complex environmental vadose zone soil samples with regard to potential ground-water contamination. This study was undertaken, using a chemical mass balance approach, to determine the distribution of radiolabeled carbon, parent compounds, and transformation products of the radiolabeled PAH compounds, benzo(a)pyrene and pyrene, among aqueous, gas, and solid phases of a non-contaminated and contaminated (creosote-PCP) vadose zone soil over time of incubation. The apparent degradation of unlabeled PAHs and changes in toxicity of the water-soluble (aqueous) fraction were also measured.

The gas phase was monitored for mineralization $\left({ }^{14} \mathrm{CO}_{2}\right)$ and volatile intermediates. Aqueous, and solid phases were evaluated through sequential extraction using (1) water and (2) solvent (dichloromethane) to determine parent compound, intermediates, and ${ }^{14} \mathrm{C}$, (3) base extract (humic plus fulvic acids), to determine ${ }^{14} \mathrm{C}$ associated with extractable soil organic matter, and (4) combustion of soil to determine non-extractable ${ }^{14} \mathrm{C}$. Humification was measured as incorporation of ${ }^{14} \mathrm{C}$ into the solid phase of the soil and not extractable with water or dichloromethane, but associated with base extract and combusted soil.

Humification represented the most significant mechanism influencing fate and alteration of spiked PAHs accounting for 70 percent to 95 percent of the 
added ${ }^{14} \mathrm{C}$ over a 285 day study period. Humification occurred in poisoned as well as non-poisoned soil and indicated that abiotic processes may play a dominant role in humification processes for some chemicals in some soil systems.

ORDER FROM:

National Technical Information Service Order Department Springfield, Virginia 22161 U.S.A.

ORDER NUMBER:

PB93-118313

PUBLICATIONS:

Abbott, C. K., Sorensen, D. L., and Sims, R. C., 1992, Use and efficiency of ethylene glycol monomethyl ether and monoethanolamine to trap volatilized $\left[7-{ }^{14} \mathrm{C}\right]$ naphthalene and ${ }^{14} \mathrm{C}$ carbon dioxide: Environmental Toxicology and Chemistry, v. 11, p. 181-185.

Whelan, G. and Sims, R. C., in press, Oxidation of recalcitrant organics in subsurface systems: Hazardous Waste \& Hazardous Materials.

Abbott, C. K., and Sims, R. C., 1991, Evaluation of interphase transfer, chemical alteration, and detoxification in treatability testing for remediation of contaminated soil: Publication No. 91-20.7, Air and Waste Management Association Annual Conference, Vancouver, British Columbia, Canada, June 23-27.

Whelan, G. and Sims, R. C., 1990, Abiotic immobilization/detoxification of recalcitrant organics: Superfund '90: Proceedings of the 11th National Conference, Hazardous Materials Research Control Institute, Washington, D.C., November 26-28, p. 820-825.

Abbott, C. K. and Sims, R. C., 1989, Use of bioassays to monitor polycyclic aromatic hydrocarbon contamination in soil: Superfund '89: Proceedings of the Hazardous Materials Control Research Institute, Washington, D.C., November 27-29, p. 23-26. 


\section{COMPLETED PROJECT}

GRANT NUMBER:

$14-08-0001-G 1730$

PROJECT TITLE:

Incorporating Public Preferences in the Optimization of Urban Water Supply

Reliability: Planning Procedures and

Survey Techniques

PERFORMING ORGANIZATION: University of Colorado

PRINCIPAL INVESTIGATOR: $\quad$ C. W. Howe

START:

June 1989

FINAL DATE RECEIVED: $\quad$ December 1991

ABSTRACT:

Mail survey methods are designed to gather information on water user attitudes toward urban water supply reliability and on users' willingness-to-pay for increased reliability (willingness-to-accept compensation for lower reliability). A framework for including this willingness-to-pay in the design of water supply systems is presented. Water officials are found to be in close touch with water user preferences and believe their customers to be rational in their approach to water reliability. Water officials' and users' willingness to consider changes in reliability appears to depend on existing levels of reliability, but users seem willing to live with low reliability if water bills can be correspondingly reduced.

ORDER FROM:

ORDER NUMBER:
National Technical Information Service Order Department

Springfield, Virginia 22161 U.S.A.

PB92-161074 
GRANT NUMBER:

PROJECT TITLE:

START:

FINAL DATE RECEIVED:
14-08-0001-G1731

Applications of Statistical Methods

to Study Climate and Flooding

Fluctuations

University of Illinois

S. Changnon and K. Kunkel

July 1989

March 1992

\section{ABSTRACT:}

Because of concern about the potential hydrologic impacts of potential future climate change, historical stream flow and precipitation data were analyzed to determine whether significant temporal fluctuations in flooding and heavy precipitation event frequencies have occurred in the 20th century. The underlying justification for this effort is that a better understanding of past fluctuations is essential in order to make projections about the future. The study encompasses 80 stream gaging stations and 230 precipitation stations located in a 9-state region (III., Ind., lowa, Ky., Mich., Minn., Ohio., and Wis.) in the central United States. The time period for the study was 1921-1985. Partial duration series analyses of the daily data were used to identify extreme events using a threshold for a 1-year recurrence event. The warm season and cold season were analyzed separately. Statistical techniques, including the Kolmogorov-Smirnov test and robust regression with Huber-weighting of the residuals, were used to identify significant temporal fluctuations in event frequencies, magnitudes, and durations. Many stations did not exhibit significant fluctuations. However, upward trends in flood frequencies were found in Minn., lowa, and northern III. in the warm season, and lowa, southwestern III., and Ohio in the cold season. Trends were less noticeable in duration and magnitude. Analysis of the precipitation data indicated that the occurrence of heavy rainfall events is not well correlated with overall climate anomalies.

ORDER FROM:

\author{
National Technical Information Service \\ Order Department \\ Springfield, Virginia 22161 \\ U.S.A.
}


ORDER NUMBER:

PUBLICATIONS:

Kunkel, K. E., Changnon, S. A., and Shealy, R. T., 1991, Extreme precipitation variability: the link to temporal variability in seasonal precipitation: Proceedings of the Fifth Conference on Climate Variations, American Meteorological Society, Boston, Massachusetts, p. 90-91.

Kunkel, K. E., Changnon, S. A., and Shealy, R. T., 1991, Extreme precipitation variability: the link to temporal variability in seasonal precipitation:

Proceedings of the Seventh Conference in Applied Climatology, American Meteorological Society, Boston, Massachusetts, p. 123-126. 
GRANT NUMBER:

PROJECT TITLE:

PERFORMING ORGANIZATION:

PRINCIPAL INVESTIGATOR:

START:

FINAL DATE RECEIVED:

\section{4-08-0001-G1735}

Sources and Accumulation of Trace

Metals in Sediments and the Asiatic

Clam, Corbicula Fluminea, in Two

South Carolina Watersheds

South Carolina Department of Health and Environmental Control

J. Pickett

August 1989

September 1992

\section{ABSTRACT:}

A survey of trace element concentrations in the benthic bivalve, Corbicula fluminea, was conducted on the Santee-Cooper River Basin, South Carolina from 1989-1991 as part of a non-point source water quality assessment. Trace metal concentrations in clam tissues were examined in relation to temporal and spatial variations in river water and sediment. It was found the $\underline{C}$. fluminea was a suitable bio-indicator for monitoring trace metal inputs within the basin. Solute concentrations of $\mathrm{Cd}, \mathrm{Cu}$, and $\mathrm{Zn}$ underwent appreciable accumulation as demonstrated by strong solute versus tissue correlation and high bioconcentration factors. Conversely, the bioavailability of trace elements to $\underline{\mathrm{C}}$. fluminea was not necessarily related to sediment concentrations, as correlations were not observed between trace elements in sediment and clam tissue. In spite of lower solute and sediment concentrations, trace elements in clam tissues from the Wateree River were elevated in comparison to the Congaree River site. The differences in the bioavailability of metals observed between the watersheds was likely a function of physicochemical factors affecting the partitioning of metals between water and sediment compartments.

ORDER FROM:

ORDERNUMBER:
National Technical Information Service

Order Department

Springfield, Virginia 22161

U.S.A.

PB93-123974 


\section{COMPLEIEDPROJECI}

GRANT NUMBER:

PROJECT TITLE:

PERFORMING ORGANIZATION:

PRINCIPAL INVESTIGATOR:

START:

FINAL DATE RECEIVED:

\section{4-08-0001-G1739}

Removal of Contaminants from the Vadose Zone by Pneumatic Fracturing

New Jersey Institute of Technology

J. Schuring

July 1989

February 1992

\section{ABSTRACT:}

Pneumatic fracturing is a new process that enhances the removal and treatment of hazardous organic contaminants from the vadose zone. It consists of injecting high pressure air or other gas into contaminated geologic formations at controlled flow rates and pressures. Initial studies performed at a bench scale consistently demonstrated that fractured soils displayed 100 percent to 360 percent higher removal rates than unfractured soils. A fullscale prototype system was subsequently fabricated and field tested at two uncontaminated sites, including an unconsolidated clayey silt deposit and a sandstone/siltstone formation. At both sites, pneumatic fracturing caused significant increases in subsurface air flow typically ranging from one to two orders of magnitude. Measurement of ground surface have confirmed fractures propagated up to 16 feet from the point of injection.

Complementary theoretical studies have resulted in the development of models for: (1) pneumatic fracture initiation; and (2) dual porosity flow and mass transport in pneumatically fractured media. The study concludes that pneumatic fracturing is an effective emerging technology that can reduce treatment time of contaminated formations and extend available technologies to more difficult geologic conditions.

ORDER FROM:

ORDER NUMBER:
National Technical Information Service

Order Department

Springfield, Virginia 22161

U.S.A.

PB92-161207 


\section{PUBLICATIONS:}

Schuring, J. R., Chan, P. C., Bruening, C. T., and Librizzi, W. J., 1990, Application of pneumatic fracturing to remove contaminants from the vadose zone: Proceedings Water Quality Management of Landfills, Water Pollution Control Federation, Chicago, Illinois.

Schuring, J. R., Jurka, V., and Chan, P. C., 1991, Pneumatic fracturing of a clay formation to enhance removal of VOC's: Proceedings Fourteenth Annual Madison Waste Conference, University of Wisconsin, Madison, Wisconsin.

Ding, Y., Schuring, J. R., and Chan, P. C., 1991, Mathematical modeling for removal of contaminants by pneumatic fracturing: Proceedings Second International Conference on Industrial and Applied Mathematics, Washington, D.C.

Pisciotta, T., Pry, D., Schuring, J. R., Chan, P. C., and Chang, J., 1991, Enhancement of volatile organic extraction in soil at an industrial site: Proceedings of FOCUS Conference on Eastern Regional Ground Water Issues, National Water Well Association, Portland, Maine.

Ding, Y., Chan, P. C., and Schuring, J., 1991, Simulation of contaminant removal in vadose zone by pneumatic fracturing: Proceedings Canadian Congress on Applied Mechanics, Winnipeg, Manitoba.

Schuring, J. R., Jurka, V., and Chan, P. C., 1991, Pneumatic fracturing to remove VOC's: Remediation Journal, Executive Enterprises Publications, New York, v. 2, n. 1 .

Papanicolaou, P., 1989, Laboratory model studies of pneumatic fracturing of soils to remove volatile organic compounds: M.S. Thesis, Department of Civil and Environmental Engineering, New Jersey Institute of Technology, Newark, New Jersey.

Shah, N. P., 1991, Study of pneumatic fracturing to enhance vapor extraction of the vadose zone: M.S. Thesis, Department of Civil and Environmental Engineering, New Jersey Institute of Technology, Newark, New Jersey.

$\mathrm{Ng}$, Norman, 1991, Enhancement of air flow and contaminant removal in fractured soil: M.S. Project, Department of Civil and Environmental Engineering, New Jersey Institute of Technology, Newark, New Jersey. 


\section{COMPLETED PROJECT}

GRANT NUMBER:

PROJECT TITLE:
$14-08-0001-G 1743$

Study of Model Hydrological Cycle of North America in a Version of the National Center for Atmospheric

Research's General Circulation Model

PERFORMING ORGANIZATION: Scripps Institute of Technology

PRINCIPAL INVESTIGATOR: J. Roads

START:

September 1989

FINAL DATE RECEIVED:

October 1991

This work was aimed at a better understanding of mean condition and the anomalous variability of the hydrological cycle of the atmosphere and the earth's surface. To accomplish this, we carried out a hierarchy of diagnostic experiments on systems ranging from the global scale moisture balance to the surface hydrological balance of an individual modest size (about $2000 \mathrm{~km}^{2}$ ) watershed over the central United States. These analyses employed both observed and model datasets, including (a) two numerical atmospheric circulation models that include surface hydrological budgets, (b) observations of atmospheric moisture and precipitation on a global to North America continent scale, and (c) observations of precipitation, temperature, streamflow, and upper level atmospheric circulation over two watersheds in the midwestern United States, in association with the detailed surface hydrology from a watershed model applied to these basins.

ORDER FROM:

National Technical Information Service

Order Department

Springfield, Virginia 22161

U.S.A.

ORDERNUMBER:

PB93-123925

PUBLICATIONS:

Chen, S. C., Cayan, D. R., and Roads, J. O., 1991, A numerical simulation of cool/ wet and warm/wet episodes: Proceedings of the Eighth PACLIM Workshop, Pacific Grove, March. 
Nghiem, N., 1991, Predictability of the atmospheric hydrologic cycle: Master's Thesis, Scripps Institution of Oceanography, September.

Roads, J. O., Chen, S. C., Kao, J., Langley, D., and Glatzmaier, G., 1991, Global aspects of the hydrologic cycle: Proceedings of the Fifth Conference on Climate Variations, Denver, Colorado, October.

Roads, J. O., Maisel, T. N., and Alpert, J., 1991, Evaluation of the National Meteorological Center's Medium Range Forecast Model Precipitation Forecasts: Weather and Forecasting, v. 6, p. 123-132. 


\section{COMPLEIED PROUECT}

GRANT NUMBER:

PROJECT TITLE:
14-08-0001-G1746

State Revolving Loan Funds:

Analysis of Institutional Arrangements and Distributive Consequences

PERFORMING ORGANIZATION: Auburn University

PRINCIPAL INVESTIGATORS: J. G. Heilman and G. W. Johnson

START:

May 1989

FINAL DATE RECEIVED:

March 1992

\section{ABSTRACT:}

The Water Quality Act of 1987 established state revolving funds (SRFs) as state based institutions that would provide a source of perpetual financing for water quality projects. The SRF program shifts financial and management responsibility from the Federal construction grant program to state loan programs. It gives the state substantial discretion in the design and operation of the programs. This study investigates the consequences of different SRF institutional arrangements for SRF management capacity and distributional consequences. The study finds that SRFs are extremely complex entities and that states have taken widely differing approaches to structuring their SRFs. For instance, SRFs vary in agency location, interest rates, targeting of loans, and leveraging. These and other institutional design choices significantly affect both management capacity and distributional consequences. For instance, leveraging increases resources over the short run, but depletes them over the long run, while tending to shift management responsibility from the public to the private sector. Multiple aspects of the SRF policy, when translated into institutional design choices, constrain SRF's ability to serve all its intended purposed simultaneously. However, with careful design and informed management, a state revolving fund can be a productive instrument for achieving selected policy goals.

ORDER FROM:

ORDERNUMBER:
National Technical Information Service Order Department Springfield, Virginia 22161 U.S.A.

PB92-161397 


\section{COMPLEIEDPRQNECT}

GRANT NUMBER:

$14-08-0001-G 1748$

PROJECTTITLE:

Special Water Districts: A Tool for Water Quality Management as well as Economic Efficiency

PERFORMING ORGANIZATION: University of South Dakota

PRINCIPAL INVESTIGATOR: J. Davidson

START:

July 1989

FINAL DATE RECEIVED:

May 1991

\section{ABSTRACT:}

Water districts organized under state laws control over one-half of the water in the western United States, usually in the form of irrigation districts. Throughout the corn belt, drainage districts play a central role in the infrastructure of production agriculture. The discharges from these districts constitute a principal source of water pollution. This paper explores the institutional issues raised by special districts.

ORDER FROM:

ORDER NUMBER:
National Technical Information Service Order Department

Springfield, Virginia 22161

U.S.A.

To be assigned 


\section{COMPLETED PROJECT}

GRANT NUMBER:

PROJECT TITLE:
14-08-0001-G1750

Impacts of Agricultural Production

Practices on the Quantity and Quality

of Ground Water in the Central High

Plains

PERFORMING ORGANIZATION: Oklahoma State University

PRINCIPAL INVESTIGATOR: $\quad$ H. Mapp

START:

August 1987

FINAL DATE RECEIVED:

November 1991

\section{ABSTRACT:}

This study develops and applies an analytical framework, which includes a regional programming model linked with crop yield-chemical movement and aquifer models, to evaluate the potential impacts of various water quality policy alternatives on crop production patterns, irrigation management and technology decisions, agricultural chemical use, and the quality and quantity of ground water in the Central High Plains. The analysis includes a baseline representing the current production situation and expected future conditions, and three water quality protection policies: limitations on the total quantify of nitrogen applied, limitations on per acre nitrogen applications, and restrictions on the availability of selected pesticides that have been identified as likely to leach through the plant root zone. Results consist of an initial 1990 model solution for each of five regions in the study area: Oklahoma, Texas Western, Texas Eastern, Kansas Western, and Kansas Eastern. Model solutions show the acres of wheat, sorghum, corn, and alfalfa produced under dryland conditions, and under furrow, improved furrow, sprinkler, and low energy precision application irrigation systems. Also, determined are applications and movements in runoff and percolation of nutrients and pesticides, irrigation water pumped, production, and net income associated with the baseline and alternative water quality policies. A multi-year analysis predicts changes in the pattern of dryland and irrigated crop production, irrigation system decisions, and nutrient and pesticide movements, production and net income over a 20year horizon for the baseline and water quality policies. 
ORDER FROM:

National Technical Information Service

Order Department

Springfield, Virginia 22161

U.S.A.

ORDER NUMBER:

PB92-127364

PUBLICATIONS:

Sabbagh, G. J., Norris, P. E., Geleta, S., Bernado, O. J., Elliott, R. L., Mapp, H. P., Stone, J. F., 1992, Environmental and economic impacts of pesticide and irrigation practices: EPIC-PST simulation: Journal of Production Agriculture, v. 5, n. 3. 
GRANT NUMBER:

PROJECT TITLE:
$14-08-0001-G 1752$

An Economic Evaluation of Water Marketing in a Low Transaction Cost Setting

PERFORMING ORGANIZATION: Texas A\&M Research Foundation

PRINCIPAL INVESTIGATOR: R. Griffin

START:

September 1989

FINAL DATE RECEIVED:

December 1991

\section{ABSTRACT:}

Economists recommend water marketing on theoretical grounds, but the realistic appraisal of water market institutions requires study of actual markets. Twenty years of marketing in Texas' Lower Rio Grande Valley are reviewed along with the historical development of water law and procedural requirements for transferring water rights. Data indicate that significant volumes of agricultural water have been sold to municipalities. For representative transactions involving two cities, municipal benefits from water marketing are determined to exceed agricultural costs. Attention to the unique circumstances of this region is required before extending results to other areas. Surface water market institutions should cause the market to react to return flow externalities, instream flow values, and if the protection of current economic relationships is socially desirable, secondary economic effects. Moreover, states can benefit from legal reform to enable ground-water marketing if drawdown interrelationships, ground-water exhaustibility, and secondary effects (if sanctioned) are formally confronted. Policy tools are available for limiting market excesses in the case of the several possible external effects encountered for both surface-water and ground-water issues. As a consequence, water marketing can serve the state and the Nation much more broadly than it is currently.

ORDER FROM:

ORDER NUMBER:
National Technical Information Service Order Department

Springfield, Virginia 22161

U.S.A.

PB92-161348 


\section{PUBLICATIONS:}

Griffin, R. C. and Boadu, F. O., in press, Water marketing in Texas: opportunities for reform: Natural Resources Journal.

Chang, C. and Griffin, R. C., in press, Water marketing as a reallocative institution in Texas: Water Resources Research. 


\section{COMPLEIEDPROJECT}

GRANT NUMBER:

PROJECT TITLE:

PERFORMING ORGANIZATION: Princeton University

PRINCIPAL INVESTIGATOR:

START:

FINAL DATE RECEIVED:
14-08-0001-G1753

Development of a Macro-Scale Land Surface Hydrologic Model for General Circulation Models

\section{ABSTRACT:}

The development and evaluation of a macroscale land surface hydrology model, appropriate for inclusion into atmospheric general circulation models (AGCMs), is presented. The model includes hydrologically important processes such as base flow, infiltration capacity characteristics and spatial variability in soil and runoff parameters. The model, referred to as the Variable Infiltration Capacity (VIC) model, accounts for sub-grid heterogeneity in land characteristics, and represents four major hydrologic processes. These are: (1) infiltration that varies spatially within the grid or catchment and temporally depending on the soil moisture; (2) runoff that depends non-linearly on the catchment average soil moisture; (3) evaporation where the actual amount depends on the potential evapotranspiration and the soil moisture level, and (4) an interstorm base-flow parameter that is related to the soil moisture level.

To test the model over a range of catchments and climatological regimes, a daily hydroclimatological data set was compiled for the continental United States. The data set consisted of 1009 USGS stream-flow stations and 1036 NOAA climatological stations. These data were used in a "zerodimensional" modeling framework to compare the Variable Infiltration Capacity model to the Bucket model, a land surface hydrology formulation currently used in AGCMs.

The results indicate that the VIC model reproduces the important hydrologic processes significantly better than the bucket model and is computationally efficient. The model could successfully be used as the land hydrology parameterization in current AGCMs. Future research will test the model within a AGCM in the short term. 
ORDER FROM:

ORDERNUMBER:
National Technical Information Service

Order Department

Springfield, Virginia 22161

U.S.A.

PB92-205129 


\section{COMPLETEDPROJECT}

GRANT NUMBER:

PROJECT TITLE:

PERFORMING ORGANIZATION: Oklahoma State University

PRINCIPAL INVESTIGATORS:

START:

FINAL DATE RECEIVED:
14-08-0001-G1895

Alternative Institutional Arrangements for Managing an Exhaustible Aquifer: An Analytical Hierarchy Process

R. Sharda and K. Willett

July 1990

March 1992

\section{ABSTRACT:}

One of the aspects of managing water resources is to select the most preferred institutional arrangement for water allocations. The choice of institutional arrangements will affect reallocation of water, a redistribution in wealth and economic efficiency consequences. The decision-making process of selecting the preferred institutional arrangement for managing an exhaustible aquifer can be improved if decision makers can be shown how economic efficiency considerations interact with distributional consequences of alternative institutional arrangements. This study attempts to improve the decision making process by using the analytic hierarchy process (AHP). Using the AHP to model a decision problem requires breaking the problem into a hierarchy of interrelated decision elements. Then pairwise comparisons are performed between these elements. Ratio scales are derived to estimate the relative weights that are then aggregated to compute ratings for the decision alternatives.

The economic consequences as well as distributional consequences of different institutional arrangements are derived from a set of economic optimization models. Information from these models on the economic efficiency and distributional consequences of the different institutional alternatives was used as inputs in the AHP model. The validity and usefulness of the developed model was demonstrated by testing it on various constituencies who are affected by the policy decisions. Differences among choices and relative weights given to different criteria by these individuals was also investigated. This analysis provides important insight on factors influencing the political viability of particular policy alternatives. 
ORDER FROM:

ORDER NUMBER:
National Technical Information Service

Order Department

Springfield, Virginia 22161

U.S.A.

PB92-218239 


\section{COMPLEIEDPROJECI}

GRANT NUMBER:

PROJECT TITLE:

PERFORMING ORGANIZATION:

PRINCIPAL INVESTIGATOR:

START:

FINAL DATE RECEIVED:

\section{4-08-0001-G1897}

Coping with Urban Water Shortages

During Drought: The Effects of Legal

and Administrative Factors

Southern Illinois University

B. Dziegielewski

September 1990

April 1992

\section{ABSTRACT:}

The report describes the results of a survey of 547 local water supply systems serving some 31 million residents of urban areas in the states of Alabama, California, Florida, Oklahoma, Tennessee, and Wyoming. The purpose of the survey was to determine whether and to what extent legal factors (for example, common law, statutory law, executive orders) and administrative factors (for example, rules, regulations, and procedures) influence the process of drought management. The specific objectives of the study were:

(1) to determine which legal and administrative factors were manifested during the evaluation and implementation of drought response measures during actual water shortage emergencies;

(2) to examine the opinions held by water managers regarding the role of legal and administrative factors in selecting and implementing drought response measures; and

(3) to examine the importance of legal and administrative factors relative to other considerations in drought response decision making.

In addition to examining the legal and administrative aspects of drought management, the survey included an assessment of the current status of drought preparedness and long-term drought protection among the responding water systems. 
ORDER FROM:

ORDER NUMBER:
National Technical Information Service

Order Department

Springfield, Virginia 22161

U.S.A.

PB92-205145 


\section{COMPLEIED PRQNECT}

GRANT NUMBER:

PROJECT TITLE:

PERFORMING ORGANIZATION:

PRINCIPAL INVESTIGATOR:

START:

FINAL DATE RECEIVED:
14-08-0001-G1901

Effective Management of Water Resources:

A Function of Geomorphology and Instream Flow Requirements

Arizona State University

J. Stromberg

September 1990

October 1992

\section{ABSTRACT:}

Stream water management in the arid west is facing new challenges as the values of natural resources are being recognized. Dendroecological procedures (for example, development of models relating radial growth rate of riparian trees to instream flow volume) in conjunction with geomorphological site characterization can be used to guide water management. Data collected within the eastern Sierra Nevada of California indicated that valley geomorphology, and specifically valley floor width, can be used as an index for identifying riparian sites where growth of Populus trichocarpa is most directly linked to surface flow volume, and thus most sensitive to changes in flow volume. Instream flow models indicted that riparian tree growth was significantly related to surface flow at twenty sites encompassing a range of geomorphological conditions. However, the closet linkage between growth and flow occurred at sites in wide, unconstrained valleys, and these sites would thus be expected to have greatest riparian decline as a result of flow diversion. Conversely, riparian vegetation would be expected to show the greatest response to restoration of surface flow volume in wide valley settings where stream gradients are low and stream channels are wide.

ORDER FROM:

ORDER NUMBER:
National Technical Information Service

Order Department

Springfield, Virginia 22161

U.S.A.

PB93-123669 


\section{COMPLEIED PROJECI}

GRANT NUMBER:

PROJECT TITLE:
14-08-0001-G1913

In-Situ Solvent Extraction for Remediation of Coal Tar Sites

PERFORMING ORGANIZATION: Carnegie Mellon University

PRINCIPAL INVESTIGATORS: R. Luthy and D. Dzombak

START:

August 1990

FINAL DATE RECEIVED:

October 1992

\section{ABSTRACT:}

The report presents the results of an initial assessment of the feasibility of solvent extraction for removing coal tar from the subsurface on for treating contaminated soil excavated at manufactured gas plant (MGP) sites. In situ solvent extraction would involve injection, recovery, and reclamation for reinjection of an environmentally-benign, water-miscible solvent. Both laboratory experiments and engineering evaluations were performed to provide a basis for the initial feasibility assessment. Laboratory work included identification and evaluation of promising solvents, measurement of fundamental properties of coal tar-solvent-water systems, and measurement of rates of dissolution of coal tar in porous media into flowing solvent-water solutions. Engineering evaluations involved identification of common hydrogeologic features and contaminant distributions of MGP sites, and identification and evaluation of possible injection-recovery well deployment schemes. A coupled flow-chemistry model was developed for simulation of the in situ process and evaluation of the well deployment schemes. Results indicate that in situ solvent extraction may be able to recover a significant amount of coal tar from the subsurface within a reasonable time frame (on the order of one year or so), provided that subsurface conditions are conducive to process implementation. Some important implementation issues remain to be addressed.

ORDER FROM:

ORDER NUMBER:
National Technical Information Service

Order Department

Springfield, Virginia 22161

U.S.A.

PB93-118347 


\section{COMPLEIED PRQNECT}

GRANT NUMBER:

PROJECT TITLE:

PERFORMING ORGANIZATION:

PRINCIPAL INVESTIGATOR:

START:

FINAL DATE RECEIVED:
14-08-0001-G1945

Effects of Uniconazole on Plant Growth and Water Use

Oklahoma State University

J. Henderson

September 1990

September 1992

\section{ABSTRACT:}

Pyracantha, photinia, and dwarf Burford holly were treated with a foliar application or medium drenchs of uniconazole at three rates to determine uniconazole effects on plant growth. Pyracantha also received a foliar application or medium drenchs of uniconazole to determine its effect on plant water relations. Height, width, leaf area per plant and dry weight of all species decreased as uniconazole drench rate increased. Foliar applications were less effective than drenches in all species. Chlorophyll content of pyracantha increased with uniconazole rate regardless of application methed. Leaf $N, P$, and $\mathrm{Zn}$ increased in pyracantha and photinia with increasing medium drench rate but only $\mathrm{P}$ was increased in holly. $\mathrm{Zn}$ also increased in pyracantha and photinia with foliar applications but only $N$ in photinia and $P$ in pyracantha increased with increasing foliar application rate. Uniconazole did not affect leaf water potential, leaf conductance, or transpiration rate in photinia that was exposed to limited moisture.

ORDER FROM:

ORDER NUMBER:
National Technical Information Service Order Department Springfield, Virginia 22161 U.S.A.

PB93-118321 